\title{
Recent Advances of Nanoremediation Technologies for Soil and Groundwater Remediation: A Review
}

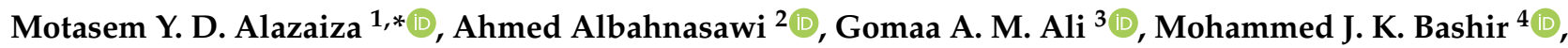 \\ Nadim K. Copty ${ }^{5}{ }^{(0}$, Salem S. Abu Amr ${ }^{6}{ }^{(0}$, Mohammed F. M. Abushammala ${ }^{7}{ }^{(0)}$ and Tahra Al Maskari ${ }^{1}$
}

1 Department of Civil and Environmental Engineering, College of Engineering, A'Sharqiyah University, Ibra 400, Oman; tahra.almaskari@asu.edu.om

2 Department of Environmental Engineering-Water Center (SUMER), Gebze Technical University, Kocaeli 41400, Turkey; ahmedalbahnasawi@gmail.com

3 Chemistry Department, Faculty of Science, Al-Azhar University, Assiut 71524, Egypt; gomaasanad@azhar.edu.eg

4 Department of Environmental Engineering, Faculty of Engineering and Green Technology (FEGT), Universiti Tunku Abdul Rahman, Kampar 31900, Malaysia; jkbashir@utar.edu.my

5 Institute of Environmental Sciences, Bogazici University, Istanbul 34342, Turkey; ncopty@boun.edu.tr

6 Faculty of Engineering, Demir Campus, Karabuk University, Karabuk 78050, Turkey; sabuamr@hotmail.com

7 Department of Civil Engineering, Middle East College, Knowledge Oasis Muscat, Muscat 135, Oman; mabushammala@mec.edu.om

* Correspondence: my.azaiza@gmail.com

\section{check for}

updates

Citation: Alazaiza, M.Y.D. Albahnasawi, A.; Ali, G.A.M.; Bashir, M.J.K.; Copty, N.K.; Amr, S.S.A.; Abushammala, M.F.M.; Al Maskari, T. Recent Advances of Nanoremediation Technologies for Soil and Groundwater Remediation: A Review. Water 2021, 13, 2186. https://doi.org/10.3390/ w13162186

Academic Editor: Sergi Garcia-Segura and Chin-Pao Huang

Received: 29 May 2021

Accepted: 5 August 2021

Published: 10 August 2021

Publisher's Note: MDPI stays neutral with regard to jurisdictional claims in published maps and institutional affiliations.

Copyright: (C) 2021 by the authors. Licensee MDPI, Basel, Switzerland. This article is an open access article distributed under the terms and conditions of the Creative Commons Attribution (CC BY) license (https:/ / creativecommons.org/licenses/by/ $4.0 /)$.

\begin{abstract}
Nanotechnology has been widely used in many fields including in soil and groundwater remediation. Nanoremediation has emerged as an effective, rapid, and efficient technology for soil and groundwater contaminated with petroleum pollutants and heavy metals. This review provides an overview of the application of nanomaterials for environmental cleanup, such as soil and groundwater remediation. Four types of nanomaterials, namely nanoscale zero-valent iron (nZVI), carbon nanotubes (CNTs), and metallic and magnetic nanoparticles (MNPs), are presented and discussed. In addition, the potential environmental risks of the nanomaterial application in soil remediation are highlighted. Moreover, this review provides insight into the combination of nanoremediation with other remediation technologies. The study demonstrates that nZVI had been widely studied for high-efficiency environmental remediation due to its high reactivity and excellent contaminant immobilization capability. CNTs have received more attention for remediation of organic and inorganic contaminants because of their unique adsorption characteristics. Environmental remediations using metal and MNPs are also favorable due to their facile magnetic separation and unique metal-ion adsorption. The modified nZVI showed less toxicity towards soil bacteria than bare nZVI; thus, modifying or coating nZVI could reduce its ecotoxicity. The combination of nanoremediation with other remediation technology is shown to be a valuable soil remediation technique as the synergetic effects may increase the sustainability of the applied process towards green technology for soil remediation.
\end{abstract}

Keywords: environmental ecotoxicity; nanoremediation; nZVI; CNTs; remediation process; soil remediation

\section{Introduction}

Contaminated soil and groundwater, especially in industrialized and urban areas, is a widespread problem that presents extreme risks to the environment and humans [1,2]. Numerous studies have focused on the remediation of soil, groundwater, wastewater, and landfill leachate polluted by various contaminants [3,4]. Soil and groundwater remediation can be broadly classified according to the place of remediation, which can be ex situ or in situ. For ex situ remediation, the polluted soil or groundwater is recovered from the subsurface and treated on the same site or transferred to another site for treatment [5]. In contrast, 
in situ remediation is when the contaminated soil or groundwater is remediated directly in the subsurface. The in situ remediation process is often preferred because it is cheaper than the ex situ remediation process [2,6]. For example, according to Chany et al. [7], the remediation cost of removal and replacement of contaminated soil is very expensive (on the order of \$3 million/ha), which is considered a big challenge for developing countries in terms of environmental sustainability practice [7].

Reducing pollution to a desirable and safe level is the main target of soil and groundwater remediation processes. Physical, chemical, and biological technologies have been used to achieve this goal for soil and groundwater remediation. In general, several factors play a significant role in the selection of the optimal soil and groundwater remediation, including soil properties and contaminants and the nature of selected and designed remediation technology [8]. Conventional methods such as pump-and-treat involve pumping groundwater by wells and removal of contaminants from the extracted groundwater by ex situ methods such as carbon adsorption, air stripping, chemical oxidation/precipitation, or biological reactors. However, these methods are associated with high operating costs and contaminated waste production [4]. For groundwater and soil contaminated with organic contaminants in the form of dense nonaqueous phase liquids (DNAPLs), emergent remediation technology such as surfactant enhanced remediation (SER) has been shown to be effective. Nevertheless, these technologies are associated with risks; with the decrease in interfacial force of DNAPLs, uncontrolled vertical movement may occur [9].

In recent years, nanotechnology has been increasingly considered in a broad range of fields. Nanoparticles (NPs) have many essential and promising properties due to their enabled functions in many sectors [10-13]. NPs are produced by combining multidisciplinary fields such as molecular level manufacturing principles and engineering. Generally, nanotechnology is a technique that constructs particles in a size range of 1-100 nanometers, studies the physical phenomena related to those particles and applying these in many sectors [4]. Nanotechnology is being used in many sectors such as the chemical, electrical, biomedical, and biotechnology industries. While many industries produce and use various forms of nanomaterials, there are many attempts to use nanotechnology for environmental protection activities such as water and wastewater treatment, pollution control, and treatment/remediation of contaminated soil and groundwater [14].

Technologies that apply nanoremediation for contaminated sites have been used in recent years (2009 till now). Studies conducted to evaluate nanoremediation technologies are mostly bench-scale with few field-scale applications [2]. The main advantages of using nanoremediation for soil and groundwater remediation, especially for extensive site cleaning, are reduced cost and cleanup time, complete degradation of some contaminants without the need for the disposal of polluted soil and without the need to transfer the soil or pump groundwater $[14,15]$.

Nanoremediation technologies involve the use of reactive NPs for conversion and detoxification of contaminants. The main mechanisms for remediation by NPs are catalysis and chemical reduction [14,16]. In addition, adsorption is another removal mechanism facilitated by the NPs since NPs have high surface-area-to-mass ratios and different distribution of active sites, increasing the adsorption ability [17]. Many engineering NPs have highly feasible characteristics for in situ remediation applications due to their innovative surface coating and minute size. In addition, NPs can diffuse and penetrate the tiny spaces in the subsurface and be suspended in groundwater for a long time; compared to microparticles, NPs can potentially travel long distances and achieve larger spatial distribution [14].

The physical movement of NPs and/or transport in groundwater is dominated by random motion or Brownian movement rather than the wall effect as a result of their nanoscale characteristics [18]. Thus, compared to microscale particles, which are strongly influenced by gravity sedimentation due to their density and large size, the movement of NPs is not controlled by gravity sedimentation, remaining suspended in groundwater during the remediation process. Thus, NPs afford a functional treatment approach allowing direct injection into the subsurface where pollutants are present [14]. 
Several studies have revealed the potential use of nanoremediation for soil and groundwater [19-22]. However, the environmental effects of those NPs are still unclear and need more investigation to understand the environmental fate and toxicity of NPs, as these issues are crucial for environmental protection practice.

The use of nanomaterials for soil and groundwater remediation has been widely tested at the laboratory level against a large number of contaminants, offering promising results $[23,24]$. However, nanomaterials may pose positive or negative impacts on living organisms, the environment, society, and the economy, which should be evaluated in a case-specific context. Appropriate documentation of nanoremediation risks, field-scale validation of remediation results, science-policy interface consultations, and suitable market development initiatives are ways to increase the popularity and acceptability of nanoremediation technologies [25]. Savolainen et al. [26] stated that the fundamental elements of risk assessment are likely to remain and will continue to include the elements designed for other chemicals and particles, notably (1) hazard identification, (2) hazard characterization, (3) exposure assessment, and (4) risk characterization, which are the four steps of the risk assessment process [26]. However, the environmental effects of those NPs are still unclear and need more investigation to understand the environmental fate and toxicity of NPs as these issues are crucial for environmental protection practice [15,27].

Various nanomaterials have been investigated for soil and groundwater remediation, such as metal oxides, nanoscale zeolites, enzymes, carbon nanotubes and fibers, titanium dioxide, and noble metals [14]. Generally, zero-valent iron (nZVI) is most widely used for soil and groundwater remediation as nZVI is considered a suitable electron donor and highly reactive [28]. The use of these different nanomaterials will be discussed in detail in this review.

The main objective of this review is to present the recent studies and development regarding the application of nanotechnology for the remediation of soil and groundwater that are contaminated by a wide range of compounds such as hydrocarbons and heavy metals. The focus is primarily on the developments of the last decade, which has witnessed a substantial increase relating in the number of studies examine nanotechnology for the remediation of soil and groundwater. The potential impact of NP use on the environment is also presented and discussed. Finally, the feasibility of combining nanoremediation with other remediation technologies is also discussed.

\section{Relationship between Soil and Groundwater: Contaminants and Remediation}

Soil and groundwater are susceptible to pollution by a wide array of pollutants such as petroleum hydrocarbon, chlorinated solvents, and heavy metals. [29]. Selecting a proper remediation technology for a contaminated environment usually depends on contaminant characteristics and contaminated site characteristics such as physical, chemical, and biological properties. All these factors should be considered during the remediation process, design, and implication. Moreover, the time/cost constraints, the regulatory requirements, and the remediation mechanisms should be considered in the selection process.

Nevertheless, adopting risk-based management approaches is increasingly a focus of environmental researchers due to the high demand for sustainable responses to environmental pollutions $[14,30]$. The polluted environments are usually surface water, sediments, soil, and groundwater, which are mainly contaminated with low and high molecular weight petroleum hydrocarbon compounds, semi-volatile organic compounds, volatile organic compounds, polycyclic aromatic hydrocarbons (PAHs), polychlorinated biphenyls, persistent organic pollutants, organochlorinated pesticides, NAPL, hydrophobic organic compounds, heavy metals, and xenobiotics [31-33]. These pollutants may migrate or spread far from the source and seriously affect flora, fauna, and the ecosystem [30]. Managing the polluted environments requires the selection of the proper remediation technology for the pollutants, destruction, and separation methods according to many ex situ and in situ remediation methods for surface water, sediments, soil, and groundwater comprising physicochemical, biological, chemical, thermal, electromagnetic, electric, and 
ultrasonic remediation technologies [34-36]. Remediation in an aqueous environment includes remediation of groundwater and surface water polluted by contaminants, whereas soil remediation includes remediation of sediment subsoil and topsoil polluted by contaminates [37]. Soil and groundwater remediation could be conducted separately or together, depending on the concentration of contaminants and the extent of pollution. The efficiency of remediation technology depends on the design and implication based on the characteristics of polluted soil and the remediation technique. Combining one remediation technology with others sequentially or simultaneously may enhance the overall remediation process through combined or synergistic effects [38].

\section{Nanomaterials}

NPs are particles with a dimension between 1 and $100 \mathrm{~nm}$, whereas nanomaterials are materials with a dimension of $100 \mathrm{~nm}$ or less in one dimension at least [39-46]. NPs have many reaction/adsorption sites on their surface due to the large proportion of atoms [10,47]. This unique property makes NPs highly reactive with surrounding contaminants cumbered to the composition materials in the macro scale [2]. Nanomaterials can be classified as natural or manufactured. Clay, iron oxide, and organic matter are examples of naturally occurring NPs in soil composition. Manufactured NPs are either developed or synthesized with a unique property to enhance their industrial or technological applications [32,48-50]. Generally, nanomaterials can be produced by two methods; the first method is from outside to inside or from top to bottom, whereby a significant part transfers into the minor parts. The second method is from bottom to top, whereby small parts are buildup into more extensive parts [51].

Several nanomaterials have been developed for contaminant remediation, such as nZVI, nanoscale zeolites, carbon nanotubes, metal oxides, bimetallic nanoparticles (BNPs), enzymes, and titanium dioxide $\left(\mathrm{TiO}_{2}\right)$ [52-57]. Soil remediation using these three nanoremediation materials (nZVI, $\mathrm{TiO}_{2}$, and CNTs) can be found in [58].

The unique characteristics of the nanomaterials, such as high surface area, quantum size effect, ease of separation and recycling, etc., support their usage as adsorbents. For example, the ferromagnetism of iron-doped nanomaterials supports their recycling and reuse $[11,59]$. The potential for nanomaterials recyclability makes them economically attractive. The hydrophobicity of fullerene is the key factor for its adsorption properties and ease of recycling [60].

\section{Nanoremediation}

Many researchers have focused on the use and development of nanoremediation technologies for soil and groundwater remediation [4]. Nanoremediation is considered an eco-friendly technology. As a result, it is considered a feasible choice for conventional site remediation technology $[4,17,61]$.

Nanoremediation may provide a cost-effective and faster solution for site remediation. Various NPs have been used for nanoremediation, such as metal oxides, nanoscale zeolites, nanometals, carbon nanotubes, and titanium dioxide. In this section, recently published studies relating to soil and groundwater remediation using four nanotechnologies are presented. The four technologies are nanoscale nZVI, carbon nanotube, metal nanoparticle, and magnetic nanoparticle.

\subsection{Soil Nanoremediation}

The first implementation of NPs on the field scale for soil and groundwater remediation was reported 20 years ago and revealed that NPs could remain active in injected soil for up to 56 days and move with groundwater for more than $20 \mathrm{~m}$ [62]. Zhang et al. [62] reported that more than $99 \%$ of trichloroethene (TCE) could be removed from contaminated sites within a few days. 


\subsubsection{Nanoscale Zero-Valent Iron}

Injection of nZVI is well-suited to soil remediation because of its limited disruption to the environment, fast kinetics, cost-effectiveness, and non-toxic nature [63]. According to Karn et al. [63], the first synthesis and use of nZVI were reported in the 1990s. Iron nanoscale was synthesized from $\mathrm{Fe}^{2+}$ and $\mathrm{Fe}^{3+}$ to produce particles ranging from 10 to $100 \mathrm{~nm}$ [14]. nZVI was used to remove many contaminants from water, mainly halogenated organic compounds that usually contaminate soil and groundwater. They reported for the first time the effectiveness of using nZVI for detoxification and transformation of many environmental contaminants such as chlorinated organic solvents, polychlorinated biphenyls, and organochlorine pesticides.

Moreover, the authors also showed that modifying nZVI may increase process speed and efficiency. In a recent study, Tian et al. [64] characterized and investigated the application of polyvinylpyrrolidone (PVP)-enhanced nZVI to remediate TCE-contaminated soil [64]. The results showed that the size of prepared PVP-nZVI was around $70 \mathrm{~nm}$ when the isoelectric point was around 8.5. In terms of TCE removal efficiency of the investigated system, the removal of TCE was around $84.73 \%$. They concluded that the PVP-nZVI technology was promising to remediate TCE-contaminated soil. Subsequently, Reginatto et al. [65] investigated the performance of nZVI for the removal of hexavalent chromium $(\mathrm{Cr}(\mathrm{VI}))$ from clayey residual soil [65]. Five different nZVI materials to contaminant ratios were used, and three different nZVI injections pressure were applied. The result showed that the ratio between $\mathrm{nZVI}$ and $\mathrm{Cr}(\mathrm{VI})$ significantly affected removal efficiency. The removal efficiency at $(1000 / 11) \mathrm{mg} \mathrm{mg}^{-1}$ ratio was $98 \%$, whereas at $(1000 / 140) \mathrm{mg} \mathrm{mg}^{-1}$, it was $18 \%$. As the pressure increased, the contaminant leaching increased; thus, the pressure of $30 \mathrm{kPa}$ was more efficient.

In another study, Shubair et al. [66] investigated nitrate removal in porous media using nZVI and modified nZVI using $\mathrm{Cu}$ in upflow packed sand column containing a multilayer system [66]. The results revealed the optimal condition for high nitrate removal when $10 \mathrm{~cm}$ of nZVI/sand was used, where the nitrate removal efficiency was around $97 \%$. On the other hand, for Cu-modified nZVI/sand, the best condition was noted when a double $5 \mathrm{~cm}$ layer was used, where complete nitrate removal was observed. The result suggests that using nZVI in a single layer or Cu-modified nZVI in a multilayer could achieve high nitrate removal. In a subsequent study, Xue et al. [67] investigated the performance of rhamnolipid modified nZVI (R-nZVI) to reduce lead $(\mathrm{Pb})$ and cadmium (Cd) in river sediments by immobilization [67]. They demonstrated that after 42 days, $\mathrm{R}$-nZVI transformed unstable $\mathrm{Pb}$ and $\mathrm{Cd}$ to stable fractions as the residual percentage of $\mathrm{Pb}$ and $\mathrm{Cd}$ increased to reach 43.10 and $56.40 \%$, respectively. In a recent study, Blundell and Owens [19] investigated the performance of nZVI for 1,1,1-Trichloro-2,2-bis(4-chlorophenyl) ethane (DDT) removal from contaminated soil [19]. They compared the efficacy of nZVI to microscale zero-valent ( $\mu \mathrm{ZVI})$. They found that samples treated with nZVI showed around $85 \%$ reduction in DDT concentration, whereas about $11 \%$ reduction in DDT was observed when $\mu \mathrm{ZVI}$ was used. The result clearly shows the superiority of using nZVI over $\mu \mathrm{ZVI}$ on DDT removal from contaminated soil. Table 1 summarizes the main results of the recent studies conducted for soil remediation by nanoremediation technologies. The mechanism of metal ions removal using nZVI which involve reduction, oxidation, adsorption and/or precipitation, as shown in Figure 1 [19]. 
Table 1. Recent studies that employed nanoremediation methods for soil remediation.

\begin{tabular}{|c|c|c|c|c|}
\hline Nanomaterial & Contaminant & Experimental Condition & Important Results & Ref. \\
\hline PVP-nZVI & Trichloroethylene & $\begin{array}{l}\text { TCE initial concentration } 1 \mathrm{mg} \mathrm{kg}^{-1} \text {; } \\
\text { PVP-nZVI dosage } 0.01 \mathrm{~g} \mathrm{~g}^{-1}\end{array}$ & $\begin{array}{l}\text { The size of papered PVP-nZVI was around } 70 \mathrm{~nm} \text {. The isoelectric } \\
\text { point was around } 8.5 \text {. } \\
\text { In terms of TCE removal efficiency of the investigated system, the } \\
\text { removal of TCE was around } 84.73 \% \text {. }\end{array}$ & [64] \\
\hline nZVI & $\mathrm{Cr}(\mathrm{VI})$ & $\begin{array}{l}\text { Five ratios were tested }(1000 / 140 ; 1000 / 70 ; 1000 / 35 ; 1000 / 23 \text {, } \\
\left.1000 / 11 \mathrm{mg} \mathrm{mg}^{-1}\right) \text {; } \\
\text { nZVI injection pressure }(10,30,100) \mathrm{kPa} ; \\
\mathrm{Cr}(\mathrm{VI}) \text { initial concentration } 800 \mathrm{mg} \mathrm{kg}^{-1}\end{array}$ & $\begin{array}{l}\text { The removal efficiency at }(1000 / 11) \mathrm{mg} \mathrm{mg}^{-1} \text { ratio was } 98 \% \\
\text { whereas at }(1000 / 140) \mathrm{mg} \mathrm{m}^{-1} \text { was } 18 \% \text {. As the pressure } \\
\text { increased, the contaminant leaching increased, thus the pressure } \\
\text { of } 30 \mathrm{kPa} \text { was more efficient. }\end{array}$ & [65] \\
\hline nZVI and Cu modified nZVI & Nitrate & $\begin{array}{l}\text { Initial nitrate concentration }\left(45 \mathrm{mg} \mathrm{L}^{-1}\right) ; \mathrm{NO}_{3}-\mathrm{N} \\
\text { nZVI and Cu modified ( } 10 \mathrm{~g} \text { per layer); } \\
\text { Flow rate }\left(5 \mathrm{~mL} \mathrm{~min}^{-1}\right) ; \\
\text { Residence time }(99 \mathrm{~min})\end{array}$ & $\begin{array}{l}\text { One layer nZVI removed more than } 97 \% \text { of nitrate, whereas } \\
\text { two-layer } \mathrm{Cu} \text {-modified nZVI achieved complete removal. }\end{array}$ & [66] \\
\hline Rhamnolipid modified nZVI & $\mathrm{Cd}(\mathrm{II}), \mathrm{Pb}(\mathrm{II})$ & $\begin{array}{l}\text { Sediment wight } 0.5,2 \mathrm{~g} \text {; } \\
\text { R-nZVI concentration } 2.5,10 \mathrm{~mL} \text { with } 0.01,0.03,0.05,0.1 \text {, } \\
0.2 \mathrm{wt} \% \text {; } \\
\text { Reaction time } 0,7,14,21,28,35,42 \text { days }\end{array}$ & $\begin{array}{l}\text { R-nZVI was effective for heavy metal immobilization on } \\
\text { river sediment. }\end{array}$ & [67] \\
\hline $\mathrm{nZVI}$ & DDT & $\begin{array}{l}\text { nZVI dosage }(5 \% w / w) \\
\text { reaction time }(60 \mathrm{~min})\end{array}$ & $\begin{array}{l}\text { DDT removal by nZVI and } \mu \text { ZVI was } 85 \% \text { and } 11 \% \text {, respectively, } \\
\text { thus revealing the superiority of using nZVI over } \mu \text { ZVI on DDT } \\
\text { removal from contaminated soil. }\end{array}$ & [19] \\
\hline MWCNTs & $\mathrm{Cr}(\mathrm{VI})$ & $\begin{array}{l}\mathrm{Cr}(\mathrm{VI}) \text { initial concentration } 5-60 \mathrm{mg} \mathrm{L}^{-1} \\
\text { Citric acid concentration } 25-250 \mathrm{mg} \mathrm{L}^{-1} \\
\text { MWCNTs concentration } 1.25 \mathrm{mg} \mathrm{L}^{-1}\end{array}$ & $\begin{array}{l}\text { At } \mathrm{pH} 5.0, \mathrm{Cr}(\mathrm{VI}) \text { adsorption capacity could reach } 8.09 \text { and } \\
7.85 \mathrm{mg} \mathrm{g}^{-1} \text { by MWCNT-COOH and MWCNT-OH, respectively. } \\
\text { All these data suggest that the catalysis function of CNTs on the } \\
\text { reduction of } \mathrm{Cr}(\mathrm{VI}) \text { was decreased by increasing } \mathrm{pH}\end{array}$ & [69] \\
\hline $\begin{array}{l}\text { Modified carbon black } \\
\text { nanoparticle (MCBN) }\end{array}$ & Heavy metal and petroleum & $\begin{array}{l}\text { Cd initial concentration } 10 \mathrm{mg} \mathrm{kg}^{-1} \text {; } \\
\text { Ni initial concentration }\left(100 \mathrm{mg} \mathrm{kg}^{-1}\right) \text {; } \\
\text { Petroleum initial concentration }\left(2000 \mathrm{mg} \mathrm{kg}^{-1}\right) \text {; } \\
\text { Remediation time } 60 \text { days; } \\
\text { MCBN dosage }(1 \% w / w)\end{array}$ & $\begin{array}{l}\text { The result showed that the availability of heavy metals could } \\
\text { significantly decrease by using MNCB in Cd and Ni contaminated } \\
\text { soil and enhance the growth of the plant }\end{array}$ & [70] \\
\hline $\begin{array}{l}\text { Single-walled carbon nanotubes } \\
\text { (SWCNTs) and MWCNTs }\end{array}$ & $\begin{array}{l}\text { dichlorodiphenyltri- } \\
\text { chloroethane (DDT) and } \\
\text { hexachlorocyclohexane }(\mathrm{HCH})\end{array}$ & $\begin{array}{l}\text { SWCNTs and MWCNTs dosage } 0.058,0.145,0.29 \mathrm{wt} \% \text {; } \\
\text { DDT initial concentration } 3 \mathrm{mg} \mathrm{kg}^{-1} \text {; } \\
\text { HCH initial concentration } 1 \mathrm{mg} \mathrm{kg}^{-1}\end{array}$ & $\begin{array}{l}\text { CNTs could effectively treat DDTs and HCHs, and the optimum } \\
\text { condition for the SWCNTs was } 0.29 \mathrm{wt} \% \text { dosage for } 4 \text { months. The } \\
\text { results suggest that the efficiency of CNTs remediation was highly } \\
\text { dependent on dose, type, and sediment-sorbent contact time }\end{array}$ & [71] \\
\hline MWCNTs & crude oil & $\begin{array}{l}\text { MWNTs concentration } 0.1,0.5,1 \mathrm{wt} \% \\
\text { Crude oil concentration } 0.5,1,2.5,5 \mathrm{wt} \% \text {; } \\
\text { Remedation time } 30 \text { days }\end{array}$ & $\begin{array}{l}\text { The results showed that using MWCNTs can enhance the } \\
\text { degradation of hydrocarbons by increasing the total } \\
\text { microbial population }\end{array}$ & [72] \\
\hline
\end{tabular}


Table 1. Cont

Nanomaterial

Contaminant

MWCNTs and AC

DDT, $\mathrm{HCH}$

HCH initial concentration $\left(5.5 \mathrm{ng} \mathrm{g}^{-1}\right)$

AC dosage $(1,2) w t \%$

Reaction time $(30,45,150)$ day

$\mathrm{Al}_{2} \mathrm{O}_{3}, \mathrm{SiO}_{2}, \mathrm{TiO}_{2}$

$\mathrm{Zn}, \mathrm{Ni}, \mathrm{Cd}$

Metal NPs $\left(\mathrm{Al}_{2} \mathrm{O}_{3}, \mathrm{SiO}_{2}, \mathrm{TiO}_{2}\right)$ dosage $1,3 \mathrm{wt} \%$ Remediation time 30 days

Important Results

Ref.

The results suggest that the Ac was more effective than MWCNTS due to its great specific surface area. These findings revealed the promising of using carbon materials as in situ soil remediation

The results showed that $\mathrm{SiO}_{2} \mathrm{NPs}$ were feasible sorbent for

reduction of the three metals $(\mathrm{Zn}, \mathrm{CD}, \mathrm{Ni})$ in calcareous soils,

whereas $\mathrm{Al}_{2} \mathrm{O}_{3} \mathrm{NPs}$ were effective for immobilizing $\mathrm{Cd}$ and $\mathrm{Zn}$ in non-calcareous soil

\begin{tabular}{|c|c|c|c|c|}
\hline $\begin{array}{l}\text { Biochar-supported iron } \\
\text { phosphate nanoparticle }\end{array}$ & $\mathrm{Cd}$ & $\begin{array}{l}\text { Remediation time } 28 \text { days; } \\
\text { Cd initial concentration }(4.25-132.23) \mathrm{mg} \mathrm{kg}^{-1}\end{array}$ & The results indicated that after 25 days, $81.3 \%$ of $\mathrm{Cd}$ was reduced. & [75] \\
\hline $\begin{array}{l}\text { Goethite nanospheres } \\
\text { (nGoethite) and nZVI }\end{array}$ & As & $\begin{array}{l}\text { nZVI dosage }(0.5,2,5,10) \mathrm{wt} \% \\
\text { nGoethite dosage } 0.2,1,2.5 \mathrm{wt} \% \\
\text { As initial concentration } 85 \mathrm{mg} \mathrm{kg}^{-1}\end{array}$ & $\begin{array}{l}\text { Both nGoethite and nZVI are promising nanomaterials for As } \\
\text { immobilization from contaminated soil. Moreover, remediation by a } \\
\text { small dosage of nGoethite seems a promising nanoremediation for } \\
\text { effective reduction of As in soil. }\end{array}$ & [76]. \\
\hline MNPs & $\mathrm{Cd}, \mathrm{Pb}$ & $\begin{array}{l}\mathrm{Cd} \text { initial concentration } 10.91 \mathrm{mg} \mathrm{kg}^{-1} \\
\mathrm{~Pb} \text { initial concentration } 190 \mathrm{mg} \mathrm{kg}^{-1}\end{array}$ & $\begin{array}{l}\text { The results showed that the organic content of the soil negatively } \\
\text { affected the removal of the residual heavy metals, whereas the use } \\
\text { of MNPs did not change the chemical composition of the soil. }\end{array}$ & [77] \\
\hline $\mathrm{Fe}_{3} \mathrm{O}_{4} @ \mathrm{C}-\mathrm{COOH} \mathrm{MNPs}$ & $\mathrm{Pb}$ & $\begin{array}{l}\mathrm{Pb} \text { initial concentration }(737.34) \mathrm{mg} \mathrm{kg}^{-1} \\
\mathrm{Fe}_{3} \mathrm{O}_{4} @ \mathrm{C}-\mathrm{COOH} \text { MNPs dosage }(0.6, \\
1.3,2.0,2.6,3.3,4.0) \text { wt } \% \\
\text { Remediation time } 10 \text { days }\end{array}$ & $\begin{array}{l}\text { The migration of } \mathrm{Pb} \text { was highly reduced, achieving a high degree of } \\
\text { remediation of } \mathrm{Pb} \text {-contaminated soil. } \\
\text { The results suggest that } \mathrm{Fe}_{3} \mathrm{O}_{4} @ \mathrm{C}-\mathrm{COOH} \text { MNPs was a promising } \\
\text { remediations technology for lead-contaminated soil }\end{array}$ & [52] \\
\hline MNPs & As, PAH, TPH & $\begin{array}{l}\text { MNPs dosage } 0.2,1,2,5 \mathrm{wt} \% \\
\text { As initial concentration } 1305 \mathrm{mg} \mathrm{kg}^{-1} \text {; } \\
\text { PAHs initial concentration } 6777 \mathrm{\mu g} \mathrm{kg}^{-1} \\
\text { TPH initial concentration } 384 \mathrm{mg} \mathrm{kg}^{-1}\end{array}$ & $\begin{array}{l}\text { MNPs dosage of } 1 \% \text { could immobilize } 42 \% \text { of As, whereas } 92.3 \% \\
\text { was immobilized at } 5 \% \text { dosage. In terms of organic pollutants, at } \\
\text { the lowest MNPs dosage, the reductions of PAHs and TPH were } \\
89 \% \text { and } 49 \% \text {, respectively }\end{array}$ & [78] \\
\hline
\end{tabular}



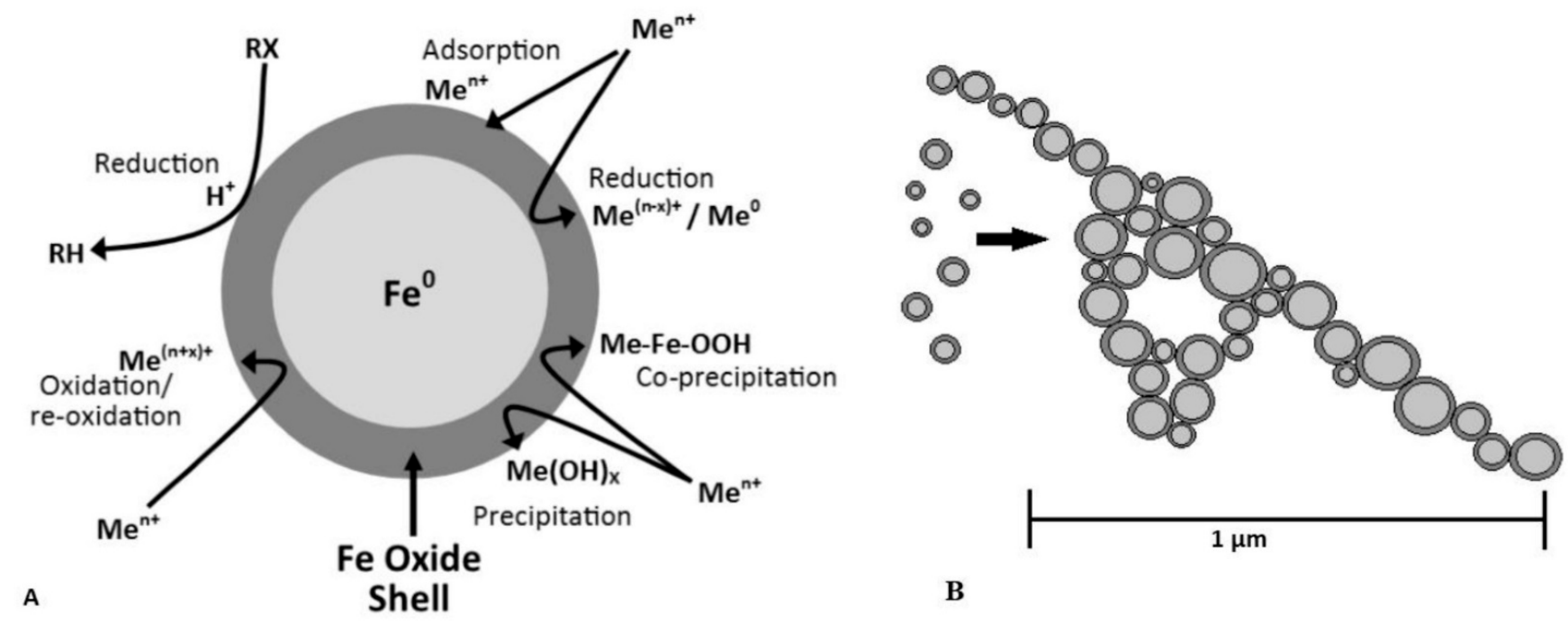

B

Figure 1. Metal ions removal using nZVI (A) is the mechanism and (B) is the particles aggregations. Reprinted with permission from [19] (2021, Elsevier).

\subsubsection{Carbon Nanotubes}

Since the beginning of their application in the water treatment industry, carbon nanotubes (CNTs) have received significant attention from many researchers due to their superior properties, especially their adsorption properties, since CNTs have a strong ability to be attached to the functional groups of pollutants [79]. CNTs can be classified as single-walled carbon tubes and multi-walled carbon nanotubes.

Many studies have been carried out to investigate the performance of CNTs in terms of soil and groundwater remediation. One such attempt has been conducted by Apul et al. [68], who evaluated the performance of microwave-assisted CNTs for removing total petroleum hydrocarbons (TPH) from the soil [68]. Results showed that after using microwave treatment for $60 \mathrm{~s}$, an $82 \%$ removal efficiency of TPH was achieved. Zhang et al. [69] assessed the remediation of $\mathrm{Cr}(\mathrm{VI})$ contaminated soil using carboxylate or hydroxylated multi-walled carbon nanotubes (MWCNT-COOH or MWCNT-OH) [69]. In addition, the effect of their catalytic activity on the reduction of $\mathrm{Cr}(\mathrm{VI})$ by citric acid was evaluated. The results showed that at $\mathrm{pH} 5, \mathrm{Cr}(\mathrm{VI})$ adsorption capacity was 8.09 and $7.85 \mathrm{mg} \mathrm{g}^{-1}$ by MWCNTs-COOH and MWCNT-OH, respectively. In a subsequent study, Cheng et al. [70] studied the efficiency of modified carbon black NPs (MCBN) for petroleum biodegradation and heavy metal immobilization in contaminated soil remediated by plantmicrobe combined remediation [70]. The result showed that $65 \%$ of petroleum degradation increased in petroleum-Ni co-contaminated soil, whereas in petroleum-Cd co-contaminated soil, the increase in petroleum degradation was $50 \%$. Moreover, the result showed that heavy metals' availability could significantly decrease by using MNCB in Cd- and Nicontaminated soil, leading to enhancing the plant's growth.

In another study, Gong et al. [80] investigated the performance of single-walled carbon nanotubes (SWCNTs) and multi-walled carbon nanotubes (MWCNTs) for the reduction of dichlorobiphenyls- chloroethane (DDT) and hexachlorocyclohexane (HCH) [80]. The authors used different concentrations of SWCNTs and MWCNTs as well as different remediation times. The result showed that CNTs could effectively treat DDTs and $\mathrm{HCHs}$. Optimum conditions for the SWCNTs were $0.29 \mathrm{wt} \%$ dosages for 4 months. In addition, the results suggest that the efficiency of CNTs remediation was highly dependent on dosage and sediment-sorbent contact time. Abbasian et al. [72] used MWCNTs to enhance the bioremediation of crude oil-contaminated soil [72]. They mixed different concentrations of 
crude oil with MWCNTs for 30 days, and then the microbial diversity of these samples was identified by fluoxetine (FLX) pyrosequencing. The results revealed that using MWCNTs can enhance the degradation of hydrocarbons by increasing the total microbial population. MWCNTs were also used to examine the performance of carbon materials to remediate DDTs and HCHs from sediment. The results showed that sediment remediated with $2 \mathrm{wt} \%$ activated carbon (AC) and MWCNTs showed $93 \%$ and 59\% decrease for DDTs, respectively, and $97 \%$ and $75 \%$ for $\mathrm{HCHs}$ in aqueous equilibrium [73]. The results suggest that the AC was more effective than MWCNTs due to its great specific surface area. These findings revealed the promising of using carbon materials as in situ soil remediation.

\subsubsection{Metal and Magnetic Nanoparticles}

The use of metal NPs to remediate and immobilize the contaminant from soil and groundwater has attracted much attention recently [74]. Many recent studies examined the performance of using metal NPs for soil remediation. One such attempt has been presented by Peikam and Jalali [74], who studied the remediation of $\mathrm{Zn}, \mathrm{Ni}$, and cadmium (Cd) from two contaminated non-calcareous and calcareous soils by $\mathrm{SiO}_{2} \mathrm{NPs}$ [74]. The result showed that the reduction of $\mathrm{Cd}$ was maximum with $3 \% \mathrm{SiO}_{2}(56.1 \%)$ and $1 \% \mathrm{Al}_{2} \mathrm{O}_{3}$ (38.3\%) for the calcareous and non-calcareous soils, respectively. In terms of $\mathrm{Zi}$, the highest reduction in calcareous and non-calcareous soil was $57.1 \%$ for $3 \% \mathrm{TiO}_{2}$ and $28.8 \%$ for $3.0 \% \mathrm{Al}_{2} \mathrm{O}_{3}$. In an earlier study, Qiao et al. [75] examined the performance of biocharsupported iron phosphate NPs stabilized by a sodium carboxymethyl cellulose composite for $\mathrm{Cd}$ remediation from contaminated soil [75]. A batch experiment with composite (soil-to-solution ratio $1 \mathrm{~g}$ : $10 \mathrm{~mL}$ ) was used. The results indicated that after 25 days, $81.3 \%$ of $\mathrm{Cd}$ was reduced. The results suggest that the investigated composite could enhance the immobilization of $\mathrm{Cd}$ in soil by reducing bioaccessibilty and leachability. In a recent study, Baragano et al. [76] compared the performance of goethite nanospheres (nGoethite) and nZVI for contaminated soil remediation [76]. The result showed that for $2 \%$ nZVI dosage, the decrease was $89.5 \%$. The soil phytotoxicity was reduced in general, and the soil parameters were not negatively affected by using nZVI to remediate the contaminated soil. On the other hand, the use of nGoethite showed an excellent result as a small dosage of nGoethite $(0.2 \%)$ could decrease the As by $82.5 \%$. However, at high dosage, the soil phytotoxicity increased as the electrical conductivity of the soil increased due to using high dosage. The results suggest that both nGoethite and nZVI are promising nanomaterials for As immobilization from contaminated soil.

Environmental remediation using magnetic NPs (MNPs) has received attention recently because of their facile separation using a magnet and special metal-ion adsorption. Several studies investigated the performance of MNPs for soil and groundwater remediation. Fan et al. (2016) examined new MNPs (core-shell $\mathrm{Fe}_{3} \mathrm{O}_{4} @ \mathrm{SiO}_{2} \mathrm{NPs}$ coated with iminodiacetic acid chelators) for contaminated soil remediation by non-magnetic heavy metals [77]. The mechanism of removal was chelation and separation by magnetic force. The results indicated that the removal rates of $\mathrm{Cd}$ and $\mathrm{Pb}$ were $84.9 \%$ and $72.2 \%$, respectively. In addition, the results demonstrated that the organic content of the soil negatively affected the removal of the residual heavy metals, whereas the use of MNPs did not change the chemical composition of the soil.

\subsection{Groundwater Nanoremediation}

The use of NPs in water treatment started in the 1990s and is therefore considered one of the newer technologies. Gillham and Hannesin (1964) were the first researchers to use the idea of using NPs on decontamination of contaminated water. They used nZVI for remediation of the halogenated group [81]. Nevertheless, Wang and Zhang (1997) conducted the first study that used NPs to remediate organo-chlorines from contaminated groundwater. They observed complete and rapid removal of several aromatic chlorinated using bimetallic NPs [82]. 


\subsubsection{Nanoscale Zero-Valent Iron}

Since 1997, various nanomaterials have been used for groundwater remediation. However, the application of nZVI for groundwater remediation has received more focus due to their low cost of production and low toxicity $[2,63,83]$. Figure 2 represents the remediation process by injection of nZVI for DNAPLs. It is reported that nZVI could be used for chlorinated organic compound remediation. Lin et al. (2018) studied the performance of polyethyleneimine (PEI)-coated nZVI (PEI-nZVI) to remediate three DNAPLs (perchloroethene (PCE), trichloroethylene, and 1,2-dichloroethene (1,2-DCE)) by direct injection in the field test [84]. The result showed that after one day of injection, a remarkable reduction in the DNAPLs was recorded. The result showed complete removal ( $>99 \%$ ) of the three DNAPLs after one day from the (PEI-nZVI) injection [84]. In a recent study, Chen et al. (2020) investigated the performance of sulfide-modified nZVI (S-nZVI) supported on biochar (BC) for TCE removal from groundwater. In addition, the effect of many factors such as the mass ratio of S-nZVI to BC, pyrolysis temperature of biochar, and initial $\mathrm{pH}$ on the TCE removal were examined [20]. The results indicated that the mass ratio of S-nZVI to BC could satisfy the amount of degradation and adsorption of TCE. The pyrolysis temperatures could influence the TCE degradation and adsorption by changing the physicochemical properties of $\mathrm{BC}$. The initial $\mathrm{pH}$ had no significant effect on the total TCE removal, whereas the degradation was enhanced at high $\mathrm{pH}$. Moreover, the result showed that within $2 \mathrm{~h}$ reaction time, 100\% of the TCE was removed at S-nZVI@BC500, where at S-nZVI@BC300 and S-nZVI@BC700, the removal efficiencies of TCE were 79.97\% and $86.4 \%$, respectively [20]. In a similar study, Chen et al. [20] studied the effects of $\mathrm{Fe} / \mathrm{S}$ molar ratio, dissolved oxygen, initial $\mathrm{pH}$, and particle aging on TCE remediations by $\mathrm{S}-\mathrm{nZVI}$ [20]. The result indicated that $\mathrm{Fe} / \mathrm{S}$ molar ratio and initial $\mathrm{pH}$ remarkably affected the TCE removal, where a higher TCE removal was obtained at Fe/S molar ratio of 60 at $\mathrm{pH}$ above 7. A slight decrease in TCE decolorization was observed when S-nZVI was aged up to 20 days, whereas a remarkable decrease was observed at an aging time of 30 days. Finally, dissolved oxygen had a small effect on TCE removal S-nZVI [85]. In another study, Zhu et al. [86] used green technology to synthesize nZVI/Cu from green tea for $\mathrm{Cr}(\mathrm{VI})$ contaminated groundwater remediation [86]. The result showed that the removal efficiency of $\mathrm{Cr}(\mathrm{VI})$ was enhanced by decreasing the initial $\mathrm{Cr}(\mathrm{VI})$ concentration and initial $\mathrm{pH}$ and increasing the temperature, while the presence of humic acids in groundwater decreased the activity of $\mathrm{nZVI} / \mathrm{Cu}$. In addition, the result indicated that at optimum conditions $(\mathrm{pH}=5$, temperature $303 \mathrm{~K})$, the $\mathrm{Cr}(\mathrm{VI})$ removal efficiency was $94.7 \%$. Finally, the results suggest that $\mathrm{nZVI} / \mathrm{Cu}$ is a promising green technology for contaminated groundwater by $\mathrm{Cr}$ (VI) [86]. Díaz et al. [21] evaluated the performance of two dosages of commercial nZVI ( 1 and $5 \%$ ) for $\mathrm{Cu}$ and/or Ni immobilization from water and acidic soil. The results showed that the presence of $\mathrm{Cu}$ affected the immobilization of $\mathrm{Ni}$, whereases the presence of $\mathrm{Ni}$ did not affect the immobilization of $\mathrm{Cu}$. The efficiency of nZVI was better in water than in soil. The use of $5 \%$ dosage completely removed $\mathrm{Cu}$ and $\mathrm{Ni}$ from water samples, where in soil samples, $5 \%$ dosage achieved $54 \%$ and $21 \%$ embolization for $\mathrm{Ni}$ and $\mathrm{Cu}$, respectively [21].

\subsubsection{Carbon Nanotubes}

In recent years, the use of CNTs for water and groundwater remediation has been increasingly attractive due to their high adsorption affinity. Many recent studies investigated the performance of CNTs for contaminated groundwater remediation. Mpouras et al. [22] investigated $\mathrm{Cr}(\mathrm{VI})$ removal from groundwater by MWCNTs. In addition, the effect of operating conditions such as MWCNTs and $\mathrm{Cr}(\mathrm{VI})$ concentration, $\mathrm{pH}$, and contact time were examined [22]. The results showed that $\mathrm{pH}$ has a significant effect on the adsorption efficiency of MWCNTs; for $\mathrm{pH}$ higher than 7, the adsorption process remarkably increased. The adsorption process increased by increasing the MWCNTs concentration. At $\mathrm{pH} 8$, the adsorption percentage increased from $85 \%$ to $100 \%$ as the concentration of MWCNTs increased from 10 to $50 \mathrm{~g} \mathrm{~L}^{-1}$ [22]. In another study, Lico et al. [87] examined the performance of MWCNTS for the removal of unleaded gasoline from water [87]. They used a lab-scale 
experiment by adding $20 \mathrm{~mL}$ of unleaded gasoline to $30 \mathrm{~mL}$ of water and adding different MWCNTs. The results indicated that a small amount of MWCNTs $(0.7 \mathrm{~g})$ could remove within 5 min a high percentage of unleaded gasoline. In another study, Liang et al. [88] investigated the efficiency of using alumina-decorated MWCNTs $\left(\mathrm{Al}_{2} \mathrm{O}_{3} / \mathrm{MWCNTs}\right)$ for simultaneous remediations of cadmium (Cd(II)) and TCE from groundwater [88]. They conducted a batch experiment for a wide range of conditions. The result showed that the maximum adsorption capacities achieved by $\mathrm{Al}_{2} \mathrm{O}_{3} / \mathrm{MWCNTs}$ were $19.84 \mathrm{mg} \mathrm{g}^{-1}$ for $\mathrm{Cd}$ (II) and $27.21 \mathrm{mg} \mathrm{g}^{-1}$ for TCE. The results suggest that $\mathrm{Al}_{2} \mathrm{O}_{3} /$ MWCNTs could be a promising technology for $\mathrm{Cd}$ (II) and TCE-contaminated groundwater remediations [88]. Table 2 summarizes the recent works conducted in water and groundwater remediation by nanoremediation technologies.

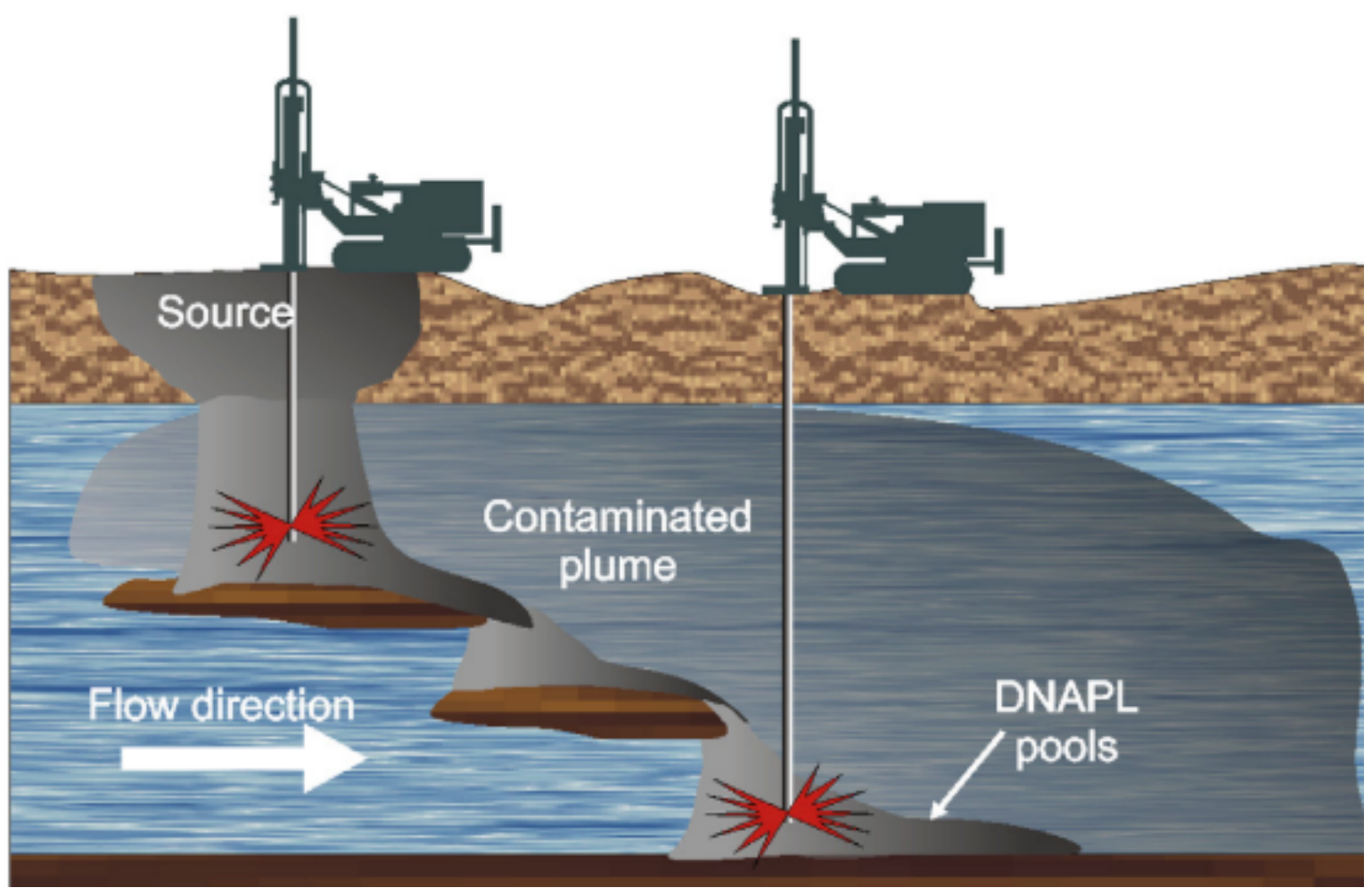

Figure 2. Remediation of an aquifer contaminated by DNAPLs injecting nZVI suspensions directly at the sources of contamination. Reprinted with permission from [83] (2014, Elsevier).

\subsubsection{Metal and Magnetic Nanoparticle}

The use of metal and magnetic NPs in water and groundwater remediation has received significant attention due to their unique properties. Ou et al. [90] studied the performance of iron-coated aluminum (Fe/ $\mathrm{Al}) \mathrm{BNPs}$ and aluminum-coated iron $(\mathrm{Al} / \mathrm{Fe})$ BNPs for the remediations of $\mathrm{Cr}(\mathrm{VI})$ from contaminated groundwater [90]. The results indicated that the $\mathrm{Cr}(\mathrm{VI})$ removal rate depended on reactive sites and the saturation concentration when $(\mathrm{Fe} / \mathrm{Al})$ was used. Moreover, the results showed that the investigated NPs could decrease $\mathrm{Cr}(\mathrm{VI})$ to $\mathrm{Cr}(\mathrm{III})$. The removal efficiency was $1.47 \mathrm{~g} \mathrm{~g}^{-1}$ when (Fe/Al) BNPs were used and $0.07 \mathrm{~g} \mathrm{~g}^{-1}$ when $(\mathrm{Al} / \mathrm{Fe}) \mathrm{BNPs}$ were used [90]. In a subsequent study, Wang et al. [91] examined the removal of $\mathrm{Cr}(\mathrm{VI})$ from contaminated groundwater using iron sulfide NPs (FeS NPs) [91]. The batch test results indicated that a high removal efficiency (1046.1 mg Cr(VI) per gram FeS NPs) was achieved when FeS NPS was used. This high removal efficiency could be attributed to three mechanisms: reduction, adsorption, and co-precipitation. In addition, they found that the $\mathrm{pH}$ significantly affected the $\mathrm{Cr}(\mathrm{VI})$ removal using FeS NPs. The results suggest that the synthesized Fe NPs could be a 
promising remediation technology for in situ remediations of $\mathrm{Cr}(\mathrm{VI})$ contaminated soil and groundwater [91]. In another study, Xie et al. [92] investigated the immobilization of selenite (Se(IV)) in soil and groundwater using Fe-Me binary oxide NPs [92]. The results showed that high $\mathrm{Se}(\mathrm{IV})$ uptake was noticed at a $\mathrm{pH}$ range of $5-8$, the typical groundwater range. According to Langmuir's maximum capacity, the adsorption capacity was $109 \mathrm{mg}$ Se(IV) per g Fe-Me NPs [92]. In another study, Dong et al. [93] examined the effect of the aging time of Fe/Ni BNPs on particle activity [93]. Moreover, they investigated the reactivity of aged $\mathrm{Fe} / \mathrm{Ni} \mathrm{BNPs}$ by examining their performance in removing tetracycline (TC). The results showed that the aged time plays a significant role in TC removal. The removal efficiency of TC was in the range of $82.3-92.5 \%$. As the aged time increased to $5-15$ days, the removal efficiency of TC decreased by $20-50 \%$ to reach around $50 \%$, due to oxidation and aggregation of the particles. Finally, the removal efficiency of TC by 90 days using aged $\mathrm{Fe} / \mathrm{Ni} \mathrm{BNPs}$ was around 30\% [93].

Groundwater remediations using MNPs have received attention recently because of their facile separation using a magnet and unique metal-ion adsorption. Many studies recently investigated the performance of MNPs for groundwater restoration. Gong et al. (2017) investigated the performance of FeS-coated iron (Fe/FeS) magnetic NPs (MNPs) for the remediation of $\mathrm{Cr}(\mathrm{VI})$-contaminated groundwater (Figure 3) [80]. The results showed that the molar ratio of S/F has a significant effect on the Fe/FeS MNPs. Increasing the S/Fe molar ratio to 0.138 decreased $\mathrm{Cr}(\mathrm{VI})$ removal by $42.8 \%$. However, a further increase of 0.207 increased the removal efficiency by $63 \%$ within $72 \mathrm{~h}$.

Moreover, the results indicated that the adsorption process of $\mathrm{Cr}(\mathrm{VI})$ by $\mathrm{Fe} / \mathrm{FeS}$ at $\mathrm{S} / \mathrm{F}$ molar ration of 0.207 fitted with a pseudo-second-order kinetic model and the sorption capacity was $69.7 \mathrm{mg} \mathrm{g}^{-1}$, which was simulated by the Langmuir isotherm model [80]. Huang and Keller [94] developed a regenerable magnetic ligand nanoparticle (Mag-ligand) to rapidly remove $\mathrm{Cd}$ and $\mathrm{Pb}$ from contaminated water [94]. The results showed high performance of mega-ligand as $\mathrm{Cd}$ and $\mathrm{Pb}$ were removed from contaminated water quickly, and $\mathrm{Cd}$ was removed in less than $2 \mathrm{~h}$ where $\mathrm{Pb}$ in less than $15 \mathrm{~min}$. The performance of mega-legend in terms of $\mathrm{Cd}$ and $\mathrm{Pb}$ was not affected by $\mathrm{pH}(3-10)$. In addition, the whole regeneration process can be achieved by washed Mega-legend easily by $1 \% \mathrm{HCl}$. The results suggest that modified mega-legend is a feasible nanoparticle for efficient, rapid, and convenient removal of $\mathrm{Cd}$ and $\mathrm{Pb}$ from the contaminated aquatic system [94]. In a recent study, Alani et al. [96] successfully synthesized zero-valent Cu NPs and examined their performance for dye removal from water [96]. The results showed that the removal time was between 5 and $13 \mathrm{~min}$ and over $90 \%$ removal efficiency was achieved, indicating that the synthesized zero-valent $\mathrm{Cu}$ nanoparticle has a great catalytic ability [96]. In another study, Li et al. [95] examined the performance of magnetic mesoporous silica NPs (MMSNPs) for the remediation of uranium $(\mathrm{U}(\mathrm{VI}))$ from high and low $\mathrm{pH}$ [95]. The result showed that MMSNPs were efficient for $\mathrm{U}(\mathrm{VI})$ removal in the $\mathrm{pH}$ range of (3.5-9.6) for artificial groundwater. They found that MMSNPs adsorption capacity can reach $133 \mathrm{~g} \mathrm{U}(\mathrm{VI})$ per $g$ MMSNPs; these results indicate that MMSNPs are a promising solution for treating $\mathrm{U}(\mathrm{VI})$ contaminated groundwater at extreme $\mathrm{pH}$ [95]. In a recent study, Ari et al. [97] successfully synthesized $\alpha-\mathrm{Fe}_{2} \mathrm{O}_{3}$ NPs via a biosynthesis method using leaf extracts of Azadirachta indica (neem) and a non-toxic precursor salt $\left(\mathrm{FeCl}_{3} \cdot 6 \mathrm{H}_{2} \mathrm{O}\right)$. In addition, they investigated the potential of using $\alpha-\mathrm{Fe}_{2} \mathrm{O}_{3} \mathrm{NPs}$ as heterogenous catalyst for tetracycline degradation. The result showed that $\alpha-\mathrm{Fe}_{2} \mathrm{O}_{3} \mathrm{NPs}$ demonstrated excellent performance as a heterogenous catalyst for degradation of tetracycline aqueous solution by the synergistic effect of the UV/Fenton system [97]. 
Table 2. Recent studies that employed nanoremediation methods for water and groundwater remediation.

\begin{tabular}{|c|c|c|c|c|}
\hline Nanomaterial & Contaminant & Experimental Condition & Important Results & Ref. \\
\hline (PEI-nZVI) & $\begin{array}{l}\text { Perchloroethene (PCE), } \\
\text { trichloroethylene (TCE) and } \\
\text { 1,2-dichloroethene (1,2-DCE) }\end{array}$ & $\begin{array}{l}\text { TCE initial concentration } 94,000 \mu \mathrm{g} \mathrm{L}^{-1} \text {; } \\
\text { 1,2-DCE initial concentration } 2800 \mu \mathrm{g} \mathrm{L}\end{array}$ & $\begin{array}{l}\text { The result showed full removal of the three DNAPLs after one } \\
\text { day from the (PEI-nZVI) injection. }\end{array}$ & {$[84,89]$} \\
\hline $\begin{array}{l}\text { Sulfide-modified nanoscale } \\
\text { zero-valent iron (S-nZVI) }\end{array}$ & Trichloroethylene (TCE) & $\begin{array}{l}\text { TCE initial concentration } 20 \mathrm{mg} \mathrm{L}^{-1} \text {; } \\
\text { S-nZVI to BC mass ratio } 1: 1,1: 3,3: 3 \text {; } \\
\text { Initial } \mathrm{pH} 3,5,7,9 \text {; pyrolysis temperatures } 300,500,700{ }^{\circ} \mathrm{C} \text {. }\end{array}$ & $\begin{array}{l}\text { The results indicated that the mass ratio of S-nZVI to BC could } \\
\text { satisfy the amount of degradation and adsorption of TCE. The } \\
\text { pyrolysis temperatures could influence the TCE degradation } \\
\text { and adsorption by changing the physicochemical properties of } \\
\text { BC. The initial pH has no significant effect on the total TCE } \\
\text { removal, whereas at high pH, the degradation was enhanced. }\end{array}$ & [20] \\
\hline S-nZVI & Trichloroethylene (TCE) & $\begin{array}{l}\text { Initial } \mathrm{pH} 5.57,7.10,8.02 \text {; } \\
\text { TCE initial concentration } 30 \mathrm{mg} \mathrm{L}^{-1} \text {; } \\
\text { Aging time } 10,20 \text {, and } 30 \text { days }\end{array}$ & $\begin{array}{l}\text { The result indicated that } \mathrm{Fe} / \mathrm{S} \text { molar ratio and initial } \mathrm{pH} \\
\text { remarkably affected the TCE removal, where a higher TCE } \\
\text { removal was obtained at Fe/S molar ratio of } 60 \text { at } \mathrm{pH} \text { above } \\
\text { than } 7 \text {. }\end{array}$ & [85] \\
\hline $\mathrm{nZVI} / \mathrm{Cu}$ & $\mathrm{Cr}(\mathrm{VI})$ & $\begin{array}{l}\mathrm{Cr}(\mathrm{VI}) \text { initial concentration } 10,10,15 \mathrm{mg} \mathrm{L}^{-1} ; \mathrm{nZVI} / \mathrm{Cu} \\
\text { concentration } 0.4 \mathrm{~g} \mathrm{~L}^{-1} ; \mathrm{pH} 5,7,9 \text {; temperature } 293,303,313 \mathrm{~K}\end{array}$ & $\begin{array}{l}\text { At optimum condition }(\mathrm{pH}=5 \text {, temperature } 303 \mathrm{~K} \text {, the } \mathrm{Cr}(\mathrm{VI}) \\
\text { removal efficiency was } 94.7 \% \text {. }\end{array}$ & [86] \\
\hline nZVI & $\mathrm{Cu}(\mathrm{II}), \mathrm{Ni}(\mathrm{II})$ & $\begin{array}{l}\text { nZVI dosage } 0,1,5 \mathrm{wt} \% \\
\text { Cu initial concentration } 1000 \mathrm{mg} \mathrm{kg}^{-1} \text {; } \\
\text { Ni initial concentration } 2000 \mathrm{mg} \mathrm{L}^{-1}\end{array}$ & $\begin{array}{l}\text { the presence of } \mathrm{Cu} \text { affected the immobilization of } \mathrm{Ni} \text {, whereases } \\
\text { the presence of } \mathrm{Ni} \text { did not affect the immobilization of } \mathrm{Cu} \text {. } \\
\text { The use of } 5 \% \text { dosage completely removed } \mathrm{Cu} \text { and } \mathrm{Ni} \text { from } \\
\text { water samples, where in soil samples, } 5 \% \text { dosage achieved } 54 \% \\
\text { and } 21 \% \text { immobilization for } \mathrm{Ni} \text { and } \mathrm{Cu} \text {, respectively. }\end{array}$ & [21] \\
\hline MWCNTs & $\mathrm{Cr}(\mathrm{VI})$ & $\begin{array}{l}\text { MWCNTs dosage } 10-50 \mathrm{~g} \mathrm{~L}^{-1} \text {; } \\
\text { Cr(VI) initial concentration } 11 \mathrm{mg} \mathrm{L}^{-1} \text { and } 250 \mathrm{\mu g} \mathrm{L}^{-1} \text {; Contact } \\
\text { time } 24 \mathrm{~h} \text {; } \mathrm{pH} \text { 3-9 }\end{array}$ & $\begin{array}{l}\text { The adsorption process was increased by increasing the } \\
\text { MWCNTs concentration. At } \mathrm{pH} 8 \text {, the adsorption percentage } \\
\text { increased from } 85 \% \text { to } 100 \% \text { as the concentration of MWCNTs } \\
\text { increased from } 10 \mathrm{~g} \mathrm{~L}^{-1} \text { to } 50 \mathrm{~g} \mathrm{~L}^{-1} \text {. }\end{array}$ & [22] \\
\hline MWCNTs & Unleaded gasoline & $\begin{array}{l}\text { MWCNTs dosage } 0.2-0.8 \mathrm{~g} \text {; } \\
\text { Reaction time } 5-120 \mathrm{~min}\end{array}$ & $\begin{array}{l}\text { The result indicated that a small amount of MWCNTs }(0.7 \mathrm{~g}) \\
\text { within } 5 \text { min could remove a high percentage of unleaded } \\
\text { gasoline. }\end{array}$ & [87] \\
\hline $\mathrm{Al}_{2} \mathrm{O}_{3} / \mathrm{MWCNTs}$ & $\mathrm{Cd}(\mathrm{II}), \mathrm{TCE}$ & $\begin{array}{l}\mathrm{Al}_{2} \mathrm{O}_{3} / \mathrm{MWCNTs} \text { dosage } 1 \mathrm{~g} \mathrm{~L}^{-1} \\
\mathrm{Cd}(\mathrm{II}) / \mathrm{TCE} \text { initial concentration } 1 \mathrm{mg} \mathrm{L}^{-1} \\
\mathrm{pH}(4-10)\end{array}$ & 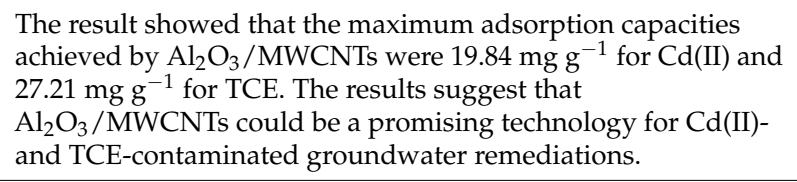 & [88] \\
\hline $\mathrm{Fe} / \mathrm{Al} \mathrm{BNPs}$ & $\mathrm{Cr}(\mathrm{VI})$ & $\begin{array}{l}\mathrm{Cr}(\mathrm{VI}) \text { initial concentration } 4-200 \mathrm{mg} \mathrm{L}^{-1} \text {; }(\mathrm{Fe} / \mathrm{Al}) \mathrm{BNPs} \text { and } \\
(\mathrm{Al} / \mathrm{Fe}) \text { BNPs dosage }(2.5) \mathrm{g} \mathrm{L}^{-1}\end{array}$ & $\begin{array}{l}\text { Removal efficiency was } 1.47 \mathrm{~g} \mathrm{~g}^{-1} \text { when }(\mathrm{Fe} / \mathrm{Al}) \text { BNPs were } \\
\text { used and } 0.07 \mathrm{~g} \mathrm{~g}^{-1} \text { when }(\mathrm{Al} / \mathrm{Fe}) \text { BNPs was used. }\end{array}$ & [90] \\
\hline
\end{tabular}


Table 2. Cont

\begin{tabular}{|c|c|c|c|c|}
\hline Nanomaterial & Contaminant & Experimental Condition & Important Results & Ref. \\
\hline Iron sulfide NPs (FeS NPs) & $\mathrm{Cr}(\mathrm{VI})$ & $\begin{array}{l}\mathrm{Cr}(\mathrm{VI}) \text { initial concentration 204.84, } \\
3464 \mathrm{mg} \mathrm{kg}^{-1} ; \mathrm{FeS} \text { NPs dosage }(28.2,42.3,67.7,84.6 \mathrm{~m} \\
117.0) \mathrm{mg} \mathrm{L}^{-1}\end{array}$ & $\begin{array}{l}\text { The batch test results indicated that a high removal efficiency } \\
\text { (1046.1 mg Cr(VI) per gram FeS NPs) was achieved when FeS } \\
\text { NPS was used. This high removal efficiency could be attributed } \\
\text { to three mechanisms: reduction, adsorption, and } \\
\text { co-precipitation. In addition, they found that the pH } \\
\text { significantly affected the Cr(VI) removal using FeS NPs. }\end{array}$ & [91] \\
\hline Fe-Me binary oxide NPs. & Selenite (Se(IV)) & $\begin{array}{l}\text { Se(IV) initial concentration } 0-10 \mathrm{mg} \mathrm{L}^{-1} \\
\text { Fe-Mn NPs dosage } 0.05 \mathrm{~g} \mathrm{~L}^{-1} \\
\text { pH } 7\end{array}$ & $\begin{array}{l}\text { The results showed that high Se(IV) uptake was noticed at a } \mathrm{pH} \\
\text { range of 5-8, a typical groundwater range. The adsorption } \\
\text { capacity was determined according to Langmuir maximum } \\
\text { capacity, where it was } 109 \mathrm{mg} \text { Se(IV) per g Fe-Me NPs. }\end{array}$ & [92] \\
\hline $\mathrm{Fe} / \mathrm{Ni} \mathrm{BNPs}$ & Tetracycline & $\begin{array}{l}\text { Ageing time } 5-90 \text { days; } \mathrm{Fe} / \mathrm{Ni} \text { BNPs dosage } 1 \mathrm{~g} \mathrm{~L}^{-1} \text {; Ni content } \\
(1,3,5) \mathrm{wt} \% \text {; } \\
\text { TC initial concentration } 100 \mathrm{mg} \mathrm{L}^{-1}\end{array}$ & $\begin{array}{l}\text { The results showed that the aging time plays significant roles in } \\
\text { TC removal. The reactivity of Fe/Ni BNPs stayed the same up } \\
\text { to } 2 \text { days as the removal efficiency of TC was in the range of } \\
\text { ( } 82.3-92.5) \% \text {. As the aging time increased to 5-15 days, the } \\
\text { removal efficiency of TC decreased by } 20-50 \% \text {, to reach around } \\
50 \% \text {, due to oxidation and aggregation of particles. Finally, the } \\
\text { removal efficacy of TC by } 90 \text { days aged Fe/Ni BNPs was } \\
\text { around } 30 \% \text {. }\end{array}$ & [93] \\
\hline FeS-coated iron $(\mathrm{Fe} / \mathrm{FeS}) \mathrm{MNPs}$ & $\mathrm{Cr}(\mathrm{VI})$ & $\begin{array}{l}\text { S/Fe molar ratio } 0,0.070,0.138,0.207 ; \mathrm{pH}_{3} .5,5,7.1,9 ; \mathrm{Cr}(\mathrm{VI}) \\
\text { initial concentration } 10,15,25,35,50,80 \mathrm{mg} \mathrm{L}^{-1}\end{array}$ & $\begin{array}{l}\text { Increasing the } \mathrm{S} / \mathrm{Fe} \text { molar ratio to } 0.138 \text { decreased } \mathrm{Cr}(\mathrm{VI}) \\
\text { removal by } 42.8 \% \text {. However, a further increase to } 0.207 \\
\text { increased the removal efficiency by } 63 \% \text { within } 72 \mathrm{~h} \text {. Moreover, } \\
\text { the results indicated that the adsorption process of } \mathrm{Cr}(\mathrm{VI}) \text { by } \\
\mathrm{Fe} / \mathrm{FeS} \text { at } \mathrm{S} / \mathrm{F} \text { molar ratio of } 0.207 \text { was fitted a } \\
\text { pseudo-second-order kinetic model, and the sorption capacity } \\
\text { was } 69.7 \mathrm{mg} \mathrm{g} \mathrm{g}^{-1} \text {, which was simulated by the Langmuir } \\
\text { isotherm model }\end{array}$ & [80] \\
\hline Magnetic ligand nanoparticle & $\mathrm{Cd}(\mathrm{II}), \mathrm{Pb}(\mathrm{II})$ & $\begin{array}{l}\mathrm{Cd}, \mathrm{Pb} \text { initial concentration } 1-100 \mathrm{mg} \mathrm{L}^{-1} \\
\mathrm{pH} 4-10 \text {; Mag-Ligand dosage } 0.2 \mathrm{~g} \mathrm{~L}^{-1}\end{array}$ & $\begin{array}{l}\text { The results showed high performance of Mega-ligand as } \mathrm{Cd} \\
\text { and } \mathrm{Pb} \text { were removed from contaminated water quickly, } \mathrm{Cd} \\
\text { was removed in less than } 2 \mathrm{~h} \text {, and } \mathrm{Pb} \text { in less than } 15 \mathrm{~min} \text {. The } \\
\text { performance of Mega-legend in terms of } \mathrm{Cd} \text { and } \mathrm{Pb} \text { was not } \\
\text { affected by } \mathrm{pH}(3-10) \text {. In addition, the full regeneration process } \\
\text { could be achieved by washed Mega-legend easily by } 1 \% \mathrm{HCl} \text {. } \\
\text { The results suggest that modified Mega-legend is a feasible } \\
\text { nanoparticle for efficient, rapid, and convenient removal of } \mathrm{Cd} \\
\text { and Pb from the contaminated aquatic system. }\end{array}$ & [94] \\
\hline MMSNPs & $\mathrm{U}(\mathrm{VI})$ & $\begin{array}{l}\mathrm{U}(\mathrm{VI}) \text { concentration } 2.5 \times 10^{-5} \mathrm{M} \text {; } \\
\text { MMSNPs dosage } 0.075 \mathrm{~g} \text { in } 7.5 \mathrm{~mL} \text { artificial groundwater }\end{array}$ & $\begin{array}{l}\text { The result showed that MMSNPs were efficient for } \mathrm{U}(\mathrm{VI}) \\
\text { removal in the } \mathrm{pH} \text { range of (3.5-9.6) for artificial groundwater. } \\
\text { They found that MMSNPs adsorption capacity can reach } 133 \mathrm{~g} \\
\mathrm{U}(\mathrm{VI}) \text { per } \mathrm{g} \text { MSNPs }\end{array}$ & [95] \\
\hline
\end{tabular}




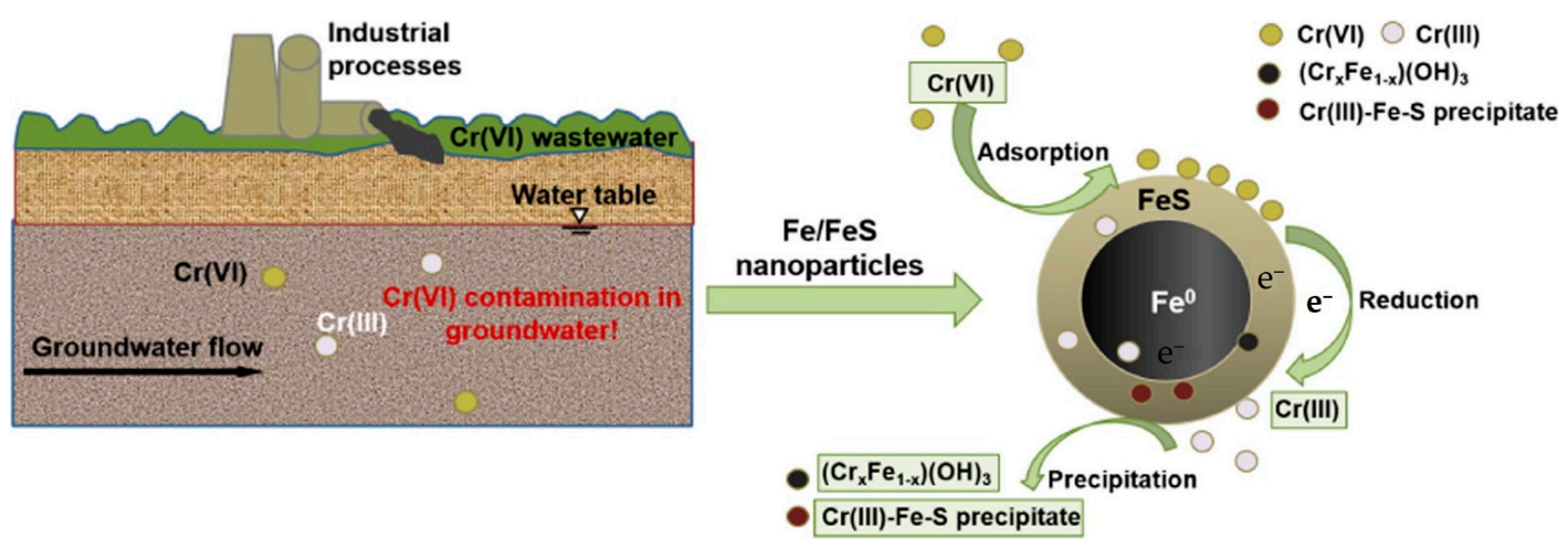

Figure 3. Groundwater remediation using Fe/FeS nanoparticles. Reprinted with permission from [80] (2017, Elsevier).

\section{Environmental Risk and Ecotoxicology}

Although nanomaterials have been used effectively for soil and groundwater remediation, exposure to nanomaterials may have deleterious effects on humans and environments. Toxicological risk assessments need data on both uptake and exposure of nanomaterials and the immediate effects of NPs when they enter the human system. However, to form a conclusion and recommendations, there are limited data in this domain. The process and factors influencing ecotoxicity are complex. Thus, many factors may determine the impact of synthesized NPs on organisms, such as dissolution potential, particle surface properties, aggregation potential, exposure environment properties, and the physiological, biological, and organism behavior when exposed to NPs [14].

Many studies highlighted the impact of nanomaterials on both humans and environments. For example, iron oxide NPs has a mutagenic impact as it may damage organisms ability to develop or reproduce [98]. Results indicated exposure to subinhibitory concentrations of amoxicillin-bound iron oxide NPs, in the presence of humic acid, and increased bacterial growth in pseudomonas aeruginosa and Staphylococcus aureus [99]. The joint effects of NPs and other contaminants on terrestrial plants are increasingly investigated but still limited. To provide a sound basis for risk assessment, more research should evaluate the joint effects under realistic conditions [100]. The size and shape of NPs ultimately determine the degree of toxicology. Therefore, not only is monitoring of NPs in soil-plant systems is not essential, but more information is needed on their size allocation and physical properties [101]. Most of the reviewed nano-risk assessment approaches are designed to serve as preliminary risk screening and/or research prioritization tools and are not intended to support regulatory decision making. Although the conventional risk assessment framework is a valuable approach, it may fail to adequately estimate the health and environmental risks from engineering nanomaterials in the near term due to overwhelming methodological limitations and epistemic uncertainties [102]. In this section, an overview of the recent studies about concerns related to the environmental risk of using nanomaterials for soil and groundwater remediation is presented.

Gómez-Sagasti et al. [103] conducted a 3 months experiment to investigate the influence of nZVI concentration (ranging from 1 to $20 \mathrm{mg} \mathrm{L}^{-1}$ ) on soil microbial properties in two types of soil: sandy-loam and clay-loam soils [103]. The results presented evidence that soil type may affect the degree of potential toxic effects on soil microbial communities by nZVI. The results showed that the accentuated inhibitory impact of nZVI on soil microorganisms in sandy-loam soil was more obvious than clay-loam soil. This can be attributed to the high organic content in clay-loam soil, which acts as a protective agent 
when nZVI was added to the soil by rendering nZVI inactive, thus prohibiting interaction with soil microorganism cells. Bacterial biomass and arylsulphatase activity, diversity, and richness were negatively influenced by remediation of sandy-loam soil by nZVI. In terms of concentration, they found no obvious concentration-response effect on the soil by nZVI application. The study suggests that many investigations are required using a wide range of soil types and soil proprieties to have clear insight into soil properties' effect and type on the impact of nZVI on soil bacteria communities [103]. In another study, Dong et al. [104] investigated the effects of carboxymethyl cellulose (CMC) surface coating on the cytotoxicity and colloidal stability of nZVI towards Escherichia coli (E. coli) and studied the interrelation between cytotoxicity and particle stability [104]. In addition, they examined the influence of $\mathrm{CMC}$ ionic strength $\left(\mathrm{Ca}^{2+}\right)$, concentration, and aging treatment on particle cytotoxicity. The results indicated that nZVI without coating harms E. coli and time- and concentration-dependent.

On the other hand, the cytotoxicity of nZVI decreased when the nZVI particles were coated with CMC. This can be attributed to the cell membrane that kept intact in CMCmodified nZVI, whereas cell membrane disruption could be observed when bare nZVI contact with E. coli. The aged nZVI and CMC-nZVI did not affect E. coli due to the $\mathrm{Fe}^{0}$ transformation to less toxic iron oxide. The toxicity of nZVI and CMC-nZVI related to the existence of $\mathrm{Ca}^{2+}$ was concentration-dependent as it can either decrease or increase. The presence of $\mathrm{Ca}^{2+}$ could decrease the toxicity of nZVI by causing aggregation and settling of nZVI.

However, the presence of $\mathrm{Ca}^{2+}$ could also increase the toxicity of nZVI by facilitating the adhesion of NPs onto the bacteria surface, forming a more toxic effect [104]. In another study, Chaithawiwat et al. [105] studied the effect of nZVI on the bacterial growth phases on four bacterial strains [105]. The results showed that lag and stationary phases for all bacterial strains were resistant to nZVI, whereas the bacterial strains in exponential and decline phases showed less resistance than lag and stationary phrases. In addition, the results indicated that increasing the nZVI concentration increased bacterial inactivation. The results suggest that it is necessary to consider the bacterial growth phase and nZVI concentration when studying the influence of nZVI on the bacteria [105]. In a subsequent study, Cheng et al. [106] examine the toxicity of S-nZVI to E. coli in an aqueous solution [106]. The result indicated that the toxicity of nZVI could be reduced by sulfidation as S/nZVI showed less toxicity at a lower F/S molar ratio, coming out from the higher iron oxide and sulfate and lower $\mathrm{Fe}^{0}$ content. The results suggest that the typical groundwater contents (i.e., $\mathrm{Ca}^{2+}, \mathrm{HCO}^{3-}, \mathrm{SO}_{4}{ }^{2-}$, and humic acid) could drop the toxicity of nZVI. In addition, in the presence of groundwater mix components, the S/nZVI toxicity was negligible. The results suggest that the implication of S/nZVI could present a low toxicity risk in the ecosystem [106]. In a recent study, $\mathrm{Li}$ et al. [107] conducted a long-term study to examine the effect of zeolite-supported nZVI (Z-nZVI) on farmland soils on bacterial communities during the remediation of metals $(\mathrm{Cd}, \mathrm{As}, \mathrm{Pb})$ [107]. The result indicated that temporary shifts in $\mathrm{pH}$-sensitive, iron resistance/sensitivity, metal resistance, and denitrifying bacteria after adding Z-nZVI were eliminated due to the soil characteristics that drove the reestablishment of the indigenous bacterial community Z-nZVI and restored the bacterial DNA replication and denitrification activity in the soil. The results suggest that Z-nZVI is a promising nanoremediation technology for long-term metal-contaminated soil remediation without ecotoxicity effects [107].

The toxicity of using CNTs in soil and groundwater remediation has been studied by many researchers [108]. However, there are insufficient data related to the effect of CNTs on both humans and the environment. Song et al. [109] studied the effects of MWCNTs different dosages $(0.5,1.0,2.0, \mathrm{wt} \%)$ on bacterial communities, especially the metabolic function, in phenanthrene contaminated sediment [109]. The results indicated that the metabolic function of microbial communities could be significantly changed by the application of high dosage (0.5-2.0, wt \%). This can be attributed to the utilization of carbon sources on Biolog ECO microplate. Remotion of phenanthrene-contaminated sediment 
with $0.5 \%$ MWCNTs presented the best microbial activity and Shannon-Wiener diversity index [109].

\section{Combined Nanoremediation with Other Remediation Technology}

The combination of nanoremediation technologies with other mitigation methods has attracted significant research in recent years. Synergetic studies can be characterized as combining multiple nanoremediation methods simultaneously or combined with soil flushing or with biotreatment. In this section, an overview of the recent work in this domain is presented.

Several studies combined many nanoremediation methods at the same time. Vilardi et al. [110] examined the combination of nZVI and CNTs for the remediation of $\mathrm{Cr}(\mathrm{VI})$, selenium (Se), and cobalt (Co) from aqueous solutions by conducted a batch experiment [110]. The result indicated that for $\mathrm{Cr}(\mathrm{VI})$, the main removal mechanism the reduction, whereas adsorption was the predominant mechanism for other metals. The results showed that the $\mathrm{Cr}(\mathrm{VI})$ removal efficiency was $100 \%$ when $\mathrm{ZVI}$ was used alone without $\mathrm{pH}$ change, whereas it decreased to around $90 \%$ when CNTs-nZVI nanocomposite was used. On the other hand, using CNTs-nZVI showed high removal efficiency for Se and Co at $90 \%$ and $80 \%$, respectively. The results suggest that the CNTs-nZVI nanocomposite showed high adsorption efficiency for remediation of heavy metals-contaminated water [110]. In another study, Zhang et al. [111] studied the performance of carboxymethyl cellulose (CMC)-stabilized nZVI composited with BC (CMC-nZVI/BC) for remediation of $\mathrm{Cr}(\mathrm{VI})$-contaminated soil [111]. The results indicated that, after 21 days, the immobilization efficiency of $\mathrm{Cr}(\mathrm{VI})$ was 19.7, 33.3, and 100\% when the dosage of CMC-nZVI/BC was 11, 27.5 , and $55 \mathrm{~g} \mathrm{Kg}^{-1}$, respectively. The results suggest that the addition of BC to CMC-nZVI could decrease the $\mathrm{Cr}(\mathrm{VI})$ transformation slightly, as a small part of CMC-nZVI could be adsorbed to biochar. The $\mathrm{Cr}_{\text {total }}$ removal efficiency was high because the reduction reaction continued to remediation [69]. In a recent study, Qian et al. [112], for the first time, investigated the performance of biochar-nZVI for the remediation of chlorinated hydrocarbon in the field [112]. They used direct-push and water pressure-driven packer techniques. The field study results demonstrated a sharp reduction of chlorinated solvents in the $24 \mathrm{~h}$ after the first injection of nZVI, but within the next two weeks, a rebound of the concentrations in groundwater was observed. However, the implementation of biochar-nZVI highly improved the removal of the chlorinated solvent from groundwater for 42 days (Figure 4). The results suggest that biochar-nZVI is a promising combined technology for chlorinated solvent contaminated groundwater remediation [112].

Galdames et al. [29] developed a new approach combining nanoremediation with bioremediation for hydrocarbon and heavy metals remediation from contaminated soil [29]. Specifically, the method uses a combination of nZVI and compost from organic waste. The results indicated that the combination of nZVI and compost could decrease the aliphatic hydrocarbons concentration up to $60 \%$ even under uncontrolled conditions. In addition, they observed a remarkable decrease in ecotoxicity in the bio-pile of soil [29]. In another study, Alabresm et al. [113] studied the combination of PVP-coated magnetite NPs with oildegrading bacteria for crude oil remediation at the lab scale [113]. The result indicated that NPs alone removed around $70 \%$ of high oil concentration after $1 \mathrm{~h}$. However, the removal efficiency did not increase due to the saturation of NPs. On the other hand, bioremediation by oil-degrading bacteria removed $90 \%$ of oil after $48 \mathrm{~h}$. Finally, the combination of NPs and oil-degrading bacteria could completely remove the oil within $48 \mathrm{~h}$. This was attributed to the sorption of oil components to NPs and following degradation by bacteria. Further investigation is needed to understand the oil removal mechanism when combining NPs with oil-degrading bacteria are used for oil remediation [113]. 


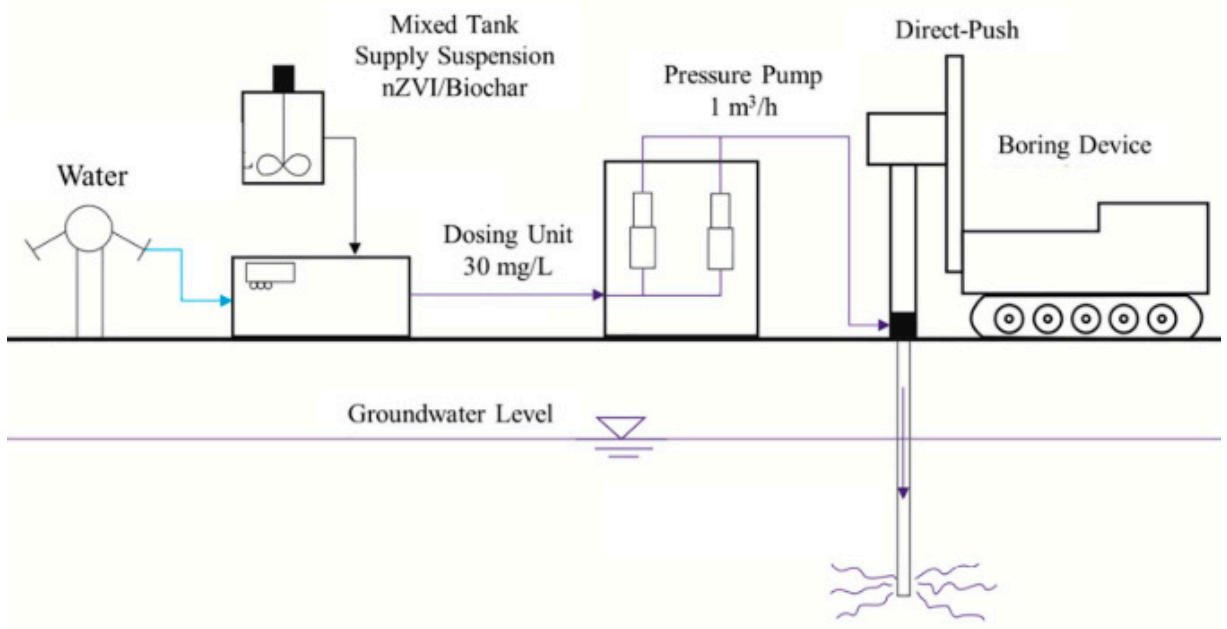

Figure 4. Step of injection procedure. Reprinted with permission from [112] (2020, Elsevier).

Recently, Czinnerova et al. [114] conducted a long-term field study that investigated the degradation of chlorinated ethenes (CEs) by using nZVI supported by electrokinetic (EK) treatment (nZVI-EK) [114]. EK may enhance the nZVI impact on soil bacteria and increased the migration and longevity of nZVI. The results indicated a rapid decrease in cis1,2-dichloroethene (CDCE) at around 70\%, followed by setting new geochemical conditions as a degradation product of CE (ethene, ethane, and methane) was observed. These new conditions enhanced the growth of soil and ground bacteria, such as organohalide-respiring bacteria. The results suggest that nZVI-EK remediation technology is a promising method for $C E$ remediation from soil and groundwater and enhanced bacteria availability in soil and groundwater [114]. In another study, Sierra et al. [115] studied a combination of soil washing and nZVI for the removal and recovery of toxic elements ( $\mathrm{As}, \mathrm{Cu}, \mathrm{Hg}, \mathrm{Pb}, \mathrm{Sb}$ ) from polluted soil (Figure 5) [115]. The results showed that a high recovery yield was obtained for $\mathrm{Pb}, \mathrm{Cu}$, and $\mathrm{Sb}$ in the magnetically separated fraction, whereas $\mathrm{Hg}$ was concentrated in a non-magnetic fraction. Taking everything into account, the soil washing efficiency was enhanced by adding nZVI, especially for a larger fraction. The results suggest that the investigated methodology opens the door for NPs' use in soil-washing remediation [115].

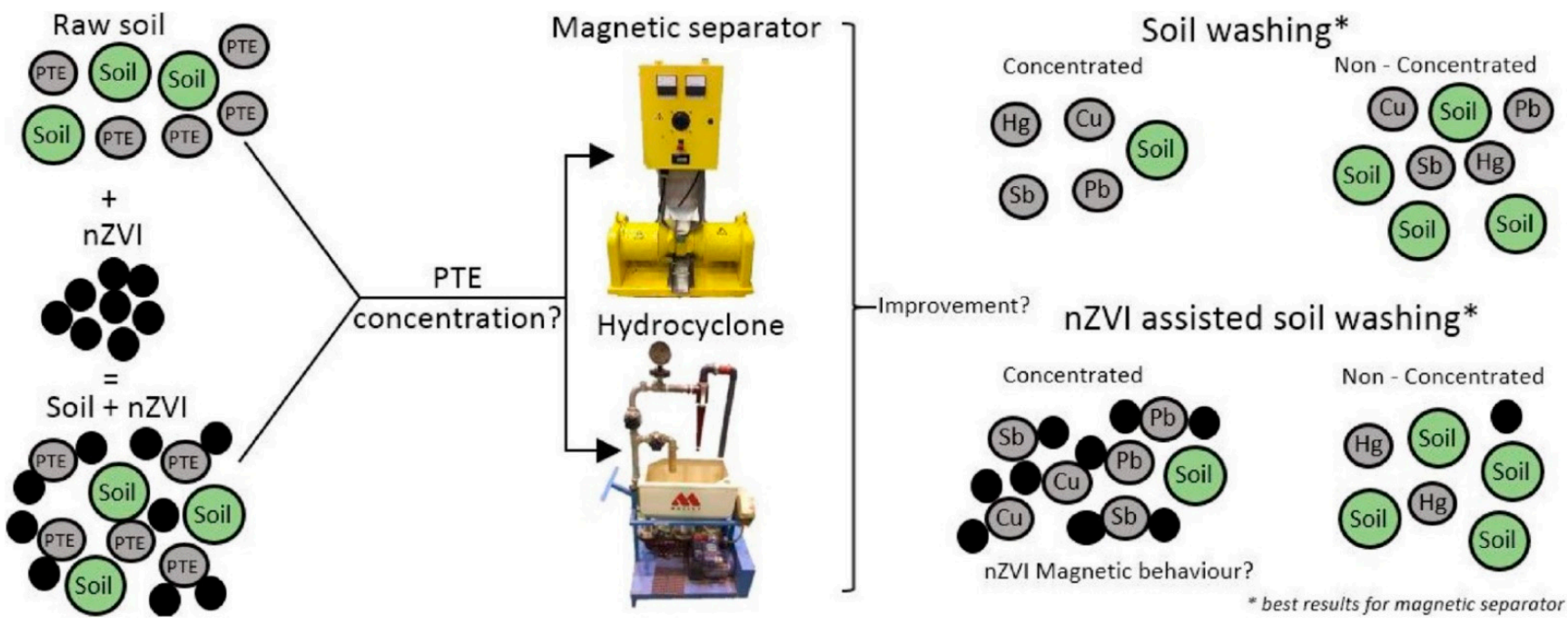

Figure 5. Soil washing assisted nZVI nanoremediation. Reprinted with permission from [115] (2018, Elsevier). 
Qu et al. [116] studied the implication of an activated carbon fiber (ACF)-supported nZVI (ACF-nZVI) composite for $\mathrm{Cr}(\mathrm{VI})$ remediation from groundwater [116]. In addition, they examined the effect of the operation condition such as nZVI amount on activated carbon fiber, initial $\mathrm{Cr}(\mathrm{VI})$ concentration, and $\mathrm{pH}$ value on the $\mathrm{Cr}(\mathrm{VI})$ removal by conducting a batch experiment. The results indicated that the aggregation of nZVI could be inhabited by $\mathrm{ACF}$, which increases the nZVI reactivity and $\mathrm{Cr}(\mathrm{VI})$ removal efficiency. The removal efficiency of $\mathrm{Cr}(\mathrm{VI})$ decreased with increasing $\mathrm{Cr}(\mathrm{VI})$ initial concentration, whereas, in an acidic environment, complete removal $(100 \%)$ of $\mathrm{Cr}(\mathrm{VI})$ was observed in $1 \mathrm{~h}$ reaction time. The proposed removal mechanism consisted of two steps: the first step was the physical adsorption of $\mathrm{Cr}(\mathrm{VI})$ on the ACF-nZVI surface area or inner layer, where the second step was a reduction of $\mathrm{Cr}(\mathrm{VI})$ to $\mathrm{Cr}(\mathrm{III})$ by nZVI [116]. In another study, Huang et al. [117] studied the activation of persulfate (PS) by using a zeolite-supported nZVI composites (PS$\mathrm{Z} / \mathrm{nZVI}$ ) system and examined its efficiency for TCE degradation. The results indicated that $\mathrm{Z} / \mathrm{nZVI}$ showed high ability towards PS activation $(1.5 \mathrm{mM})$, and high removal efficiency (98.8\%) of TCE was observed at $\mathrm{pH} 7$ within $2 \mathrm{~h}$. Moreover, the PS-Z/nZVI system showed high efficiency in terms of TCE for a wide range of $\mathrm{pH}(4-7)$ [117]. Table 3 summarizes the recent works conducted in soil and groundwater remediation by combining nanoremediation technologies with other remediation methods.

Table 3. Recent studies employed the combination of nanoremediation technologies with other remediation methods.

\begin{tabular}{|c|c|c|c|c|}
\hline Nanomaterial & Contaminant & Experimental Conditions & Important Results & Ref. \\
\hline CNTs-nZVI & $\mathrm{Cr}(\mathrm{VI}), \mathrm{Se}, \mathrm{Co}$ & $\begin{array}{l}\text { Dosage } 3 \mathrm{~g} \mathrm{~L}^{-1} \text {; Initial } \\
\text { concentration } 1-10 \mathrm{mg} \mathrm{L}^{-1} ; \mathrm{pH} 6-8\end{array}$ & $\begin{array}{l}\text { The result indicated that for } \mathrm{Cr}(\mathrm{VI}) \text {, the main removal } \\
\text { mechanism was reduction, whereas adsorption was } \\
\text { the predominant mechanism for the metals. The } \\
\text { results showed that the } \mathrm{Cr}(\mathrm{VI}) \text { removal efficiency was } \\
100 \% \text { when nZVI was used alone without the effect of } \\
\text { pH change, whereas it decreased to around } 90 \% \\
\text { when CNTs-nZVI nanocomposite was used. On the } \\
\text { other hand, using CNTs-nZVI showed high removal } \\
\text { efficiency for Se and Co at } 90 \% \text { and } 80 \% \text {, respectively. }\end{array}$ & {$[110]$} \\
\hline CMC-nZVI/BC & $\mathrm{Cr}(\mathrm{VI})$ & $\begin{array}{l}\text { CMC-nZVI/BC dosage 11, 27.5, } \\
55 \mathrm{~kg} \mathrm{~g}^{-1} ; \mathrm{Cr}(\mathrm{VI}) \text { initial } \\
\text { concentration } 800 \mathrm{mg} \mathrm{kg}^{-1}\end{array}$ & $\begin{array}{l}\text { The results indicate that, after } 21 \text { days, the } \\
\text { immobilization efficiency of Cr(VI) was } 19.7,33.3 \text {, and } \\
100 \% \text { when the dosage of CMC-nZVI/BC was 11, } \\
27.5 \text {, and } 55 \mathrm{~g} \mathrm{Kg}^{-1} \text {, respectively. }\end{array}$ & {$[69]$} \\
\hline Biochar-nZVI & $\begin{array}{l}\text { Chlorinated } \\
\text { solvents }\end{array}$ & $\begin{array}{l}\text { nZVI dosage }(30) \mathrm{g} \mathrm{L}^{-1} \text {; injection } \\
\text { depth }(3.5,4.5,5.5) \mathrm{m}\end{array}$ & $\begin{array}{l}\text { The field study results demonstrated a sharp } \\
\text { reduction of chlorinated solvents in the } 24 \mathrm{~h} \text { after the } \\
\text { first injection of nZVI, but within the next two weeks, } \\
\text { the re-bond of the concentrations in groundwater was } \\
\text { observed. However, the implementation of } \\
\text { biochar-nZVI highly improved the removal of the } \\
\text { chlorinated solvent from groundwater for } 42 \text { days. } \\
\text { The results suggest that biochar-nZVI is a promising } \\
\text { combined technology for } \\
\text { chlorinated-solvent-contaminated groundwater } \\
\text { remediation. }\end{array}$ & {$[112]$} \\
\hline $\begin{array}{l}\mathrm{nZVI} \text { combined } \\
\text { with compost from } \\
\text { organic waste }\end{array}$ & $\begin{array}{l}\text { Hydrocarbons } \\
\text { (TPH, PAHs) } \\
\text { and heavy } \\
\text { metals }\end{array}$ & $\begin{array}{l}\text { TPH initial concentration } \\
\text { (104.3) } \mathrm{mg} \mathrm{kg}^{-1} ; \text { PAHs initial } \\
\text { concentration (2.25) } \mathrm{mg} \mathrm{kg}^{-1}\end{array}$ & $\begin{array}{l}\text { The results indicated that the combination of nZVI } \\
\text { and compost could decrease the aliphatic } \\
\text { hydrocarbons concentration by up to } 60 \% \text { even under } \\
\text { uncontrolled conditions. In addition, they observed a } \\
\text { remarkable decrease in ecotoxicity in the biopile of } \\
\text { the soil. }\end{array}$ & [29]. \\
\hline $\begin{array}{l}\text { PVP-coated } \\
\text { magnetite NPs with } \\
\text { oil-degrading } \\
\text { bacteria }\end{array}$ & Crude oil & $\begin{array}{l}\text { Oil initial concentration } \\
\text { (375) } \mathrm{mg} \mathrm{L}^{-1} \text {; NPs dosage } \\
\text { (18) } \mathrm{mg} \mathrm{L}^{-1}\end{array}$ & $\begin{array}{l}\text { The result indicated that NPs alone removed around } \\
70 \% \text { of high oil concentration after } 1 \mathrm{~h} \text {. However, the } \\
\text { removal efficiency did not increase due to the } \\
\text { saturation of NPs. Bioremediation by oil-degrading } \\
\text { bacteria removed } 90 \% \text { of oil after } 48 \mathrm{~h} \text {. Finally, the } \\
\text { combination of NPs and oil-degrading bacteria could } \\
\text { completely remove the oil within } 48 \mathrm{~h}\end{array}$ & [113] \\
\hline
\end{tabular}


Table 3. Cont.

\begin{tabular}{|c|c|c|c|c|}
\hline Nanomaterial & Contaminant & Experimental Conditions & Important Results & Ref. \\
\hline nZVI-EK & $\begin{array}{l}\text { Chlorinated } \\
\text { ethenes (CEs) }\end{array}$ & $\begin{array}{l}\text { nZVI dosage } 3 \mathrm{~g} \mathrm{~L}^{-1} \text {; DC voltage } \\
24 \mathrm{~V}\end{array}$ & $\begin{array}{l}\text { The results indicated a rapid decrease in } \\
\text { cis-1,2-dichloroethene (cDCE) by around } 70 \% \text {, } \\
\text { followed by new geochemical conditions as a } \\
\text { degradation product of CE (ethene, ethane, and } \\
\text { methane) was observed. These new conditions } \\
\text { enhanced the growth of soil and ground bacteria such } \\
\text { as organohalide-respiring bacteria. The results } \\
\text { suggest that nZVI-EK remediation technology not } \\
\text { only is a promising method for CE remediation from } \\
\text { soil and groundwater but also enhanced the bacteria } \\
\text { availability in soil and groundwater. }\end{array}$ & [114] \\
\hline $\begin{array}{l}\text { Soil washing } \\
\text { assessed nZVI }\end{array}$ & $\begin{array}{l}\text { As, } \mathrm{Cu}, \mathrm{Hg} \\
\mathrm{Pb}, \mathrm{Sb}\end{array}$ & nZVI dosage (16) wt\% & $\begin{array}{l}\text { The results showed that a high recovery yield was } \\
\text { obtained for } \mathrm{Pb}, \mathrm{Cu} \text {, and } \mathrm{Sb} \text { in the magnetically } \\
\text { separated fraction, whereas } \mathrm{Hg} \text { concentrated in the } \\
\text { non-magnetic fraction. Taking everything into } \\
\text { account, the soil washing efficiency was enhanced by } \\
\text { adding nZVI, especially for a larger fraction. The } \\
\text { results suggest that the investigated methodology } \\
\text { open the door for the use of NPs in soil washing } \\
\text { remediation. }\end{array}$ & [115] \\
\hline ACF-nZVI & $\mathrm{Cr}(\mathrm{VI})$ & $\begin{array}{l}\mathrm{Cr}(\mathrm{VI}) \text { initial concentration } \\
(5,10) \mathrm{mg} \mathrm{L}^{-1}\end{array}$ & $\begin{array}{l}\text { The results indicated that the aggregation of nZVI } \\
\text { could be inhabited by the presence of ACF, which } \\
\text { increases the nZVI reactivity and } \mathrm{Cr}(\mathrm{VI}) \text { removal } \\
\text { efficiency. The removal efficiency of } \mathrm{Cr}(\mathrm{VI}) \text { decreased } \\
\text { with increasing } \mathrm{Cr}(\mathrm{VI}) \text { initial concentration, whereas, } \\
\text { in an acidic environment, full removal (100\%) of } \\
\mathrm{Cr}(\mathrm{VI}) \text { was observed in } 1 \text { h reaction time. The } \\
\text { proposed removal mechanism consisted of two steps: } \\
\text { the first step was the physical adsorption of } \mathrm{Cr}(\mathrm{VI}) \text { on } \\
\text { the ACF-nZVI surface area or inner layer, while the } \\
\text { second step was a reduction of Cr(VI) to Cr(III) } \\
\text { by nZVI }\end{array}$ & [116] \\
\hline PS-Z/nZVI & $\mathrm{TCE}$ & $\begin{array}{l}\text { TCE initial concentration } \\
(0.15) \mathrm{mM}^{\mathrm{Z}} \mathrm{Z} / \mathrm{nZVI} \text { dosage } \\
(84) \mathrm{mg} \mathrm{L}^{-1} ; \\
\text { PS concentration }(1.5) \mathrm{mM}\end{array}$ & $\begin{array}{l}\text { The results indicated that } \mathrm{Z} / \mathrm{nZVI} \text { showed high } \\
\text { ability for PS activation }(1.5 \mathrm{mM}) \text {, and high removal } \\
\text { efficiency }(98.8 \%) \text { of TCE was observed at } \mathrm{pH} 7 \\
\text { within } 2 \mathrm{~h} \text {. Moreover, the PS-Z/nZVI system showed } \\
\text { high efficiency in terms of TCE for a wide range of } \\
\mathrm{pH}(4-7) \text {. }\end{array}$ & [117] \\
\hline
\end{tabular}

\section{Conclusions}

This review aims to present the latest advances in nanoremediation of contaminated soil and groundwater. The main advantages of using nanomaterials in soil remediation are reduction in cleanup time and overall costs, decreased pollutants to nearly zero in the site, and no need to dispose of polluted soil. The wide use of nZVI nanomaterials in environmental cleanup is due to their high reactivity and high ability to immobilize heavy metals such as $\mathrm{Cd}, \mathrm{Ni}$, and $\mathrm{Pb}$. Modifying and/or coating nZVI may decrease the toxicity effects on soil microorganisms. The high adsorption capacity of CNTs is from the large surface area, which makes CNTs a great nanomaterial for organic and inorganic remediation. More studies are needed to investigate the effect of CNTs on the environment.

Soil and groundwater remediation using metal and MNPs is a promising technology due to the unique separation mechanism. Full-scale application of nanoremediation needs further evaluation, particularly in terms of efficiency and potential adverse environmental impacts. Combining nanoremediation with other remediation technology appears to be the future of soil remediation as the combination process increases the sustainable remediation practice towards green environmental protection practice.

\section{Recommendation and Future Prospective}

This review provides readers with a general overview of using nanoremediation for environmental cleanups, particularly soil and groundwater remediation. More work is 
needed to developing smarter nanomaterials for soil remediation. For instance, more advanced development could produce NPs with a high ability to work with several functions, such as interacting with hydrophilic and hydrophobic materials or catalyzing many pollutant reactions on the same particle. In addition, further research is needed to design and synthesize NPs that can remediate a wide range of contaminants; and enhance the injecting systems.

Most existing research on nanoremediation is confined to laboratory studies and modeling. Transferring these studies to in situ conditions is a challenge. Thus, more investigations are required in order to develop standard protocols and doses for the application of nanomaterials at the field level. Moreover, efforts should also focus on the application of nanoremediation in the field to understand nanoparticle's fate and transport behavior in soil, water, and sediments and how they affect the environmental variables.

Nanoremediation has been developed and evaluated over the last 20 years. There is, however, concern about its effects on both humans and the environment. With the rapid advancement of nanoremediation techniques, proper evaluation needs to be done to prevent or mitigate any potential environmental or ecological hazards.

In addition, the need for a more thorough understanding of the contaminants' removal processes and the nanomaterials behavior in nature has led to experimentation where no contaminant is present. Many researchers have examined the impacts of nanoremediation on the soil and groundwater bacteria, yet a clear insight into the interaction between nanoremediation materials such as nZVI and microbial activity is still unclear.

Author Contributions: Conceptualization and Funding, M.Y.D.A.; Writing-Original Draft Preparation, A.A. and M.Y.D.A.; Writing-Review and Editing, G.A.M.A.; N.K.C.; S.S.A.A.; M.F.M.A.; and T.A.M.; Validation, M.J.K.B. All authors have read and agreed to the published version of the manuscript.

Funding: The research leading to these results has received funding from Ministry of Higher Education, Research, and Innovation (MoHERI) of the Sultanate of Oman under the Block Funding Program, MoHERI Block Funding Agreement No. MoHERI/BFP/ASU/01/2020.

Institutional Review Board Statement: Not applicable.

Informed Consent Statement: Not applicable.

Data Availability Statement: Data is contained within the article.

Conflicts of Interest: The authors declare no conflict of interest.

\section{References}

1. Cheng, M.; Zeng, G.; Huang, D.; Lai, C.; Xu, P.; Zhang, C.; Liu, Y. Hydroxyl radicals based advanced oxidation processes (AOPs) for remediation of soils contaminated with organic compounds: A review. Chem. Eng. J. 2016, 284, 582-598. [CrossRef]

2. Thomé, A.; Reddy, K.R.; Reginatto, C.; Cecchin, I. Review of Nanotechnology for Soil and Groundwater Remediation: Brazilian Perspectives. Water Air Soil Pollut. 2015, 226, 121. [CrossRef]

3. Mateas, D.J.; Tick, G.R.; Carroll, K.C. In situ stabilization of NAPL contaminant source-zones as a remediation technique to reduce mass discharge and flux to groundwater. J. Contam. Hydrol. 2017, 204, 40-56. [CrossRef]

4. Rajan, C.S.R. Nanotechnology in Groundwater Remediation. Int. J. Environ. Sci. Dev. 2011, 2, 182-187. [CrossRef]

5. Tsai, T.T.; Kao, C.M.; Yeh, T.Y.; Lee, M.S. Chemical Oxidation of Chlorinated Solvents in Contaminated Groundwater: Review. Pract. Period. Hazard. Toxic Radioact. Waste Manag. 2008, 12, 116-126. [CrossRef]

6. Honetschlägerová, L.; Martinec, M.; Škarohlíd, R. Coupling in situ chemical oxidation with bioremediation of chloroethenes: A review. Rev. Environ. Sci. Bio/Technol. 2019, 18, 699-714. [CrossRef]

7. Chaney, R.L.; Reeves, P.G.; Ryan, J.A.; Simmons, R.W.; Welch, R.M.; Scott Angle, J. An improved understanding of soil Cd risk to humans and low cost methods to phytoextract Cd from contaminated soils to prevent soil Cd risks. Biometals 2004, 17, 549-553. [CrossRef]

8. Liu, J.-W.; Wei, K.-H.; Xu, S.-W.; Cui, J.; Ma, J.; Xiao, X.-L.; Xi, B.-D.; He, X.-S. Surfactant-enhanced remediation of oil-contaminated soil and groundwater: A review. Sci. Total Environ. 2021, 756, 144142. [CrossRef]

9. Yang, C.; Offiong, N.-A.; Zhang, C.; Liu, F.; Dong, J. Mechanisms of irreversible density modification using colloidal biliquid aphron for dense nonaqueous phase liquids in contaminated aquifer remediation. J. Hazard. Mater. 2021, 415, 125667. [CrossRef] [PubMed] 
10. Gupta, V.K.; Agarwal, S.; Sadegh, H.; Ali, G.A.M.; Bharti, A.K.; Hamdy, A.S. Facile route synthesis of novel graphene oxide- $\beta$ cyclodextrin nanocomposite and its application as adsorbent for removal of toxic bisphenol A from the aqueous phase. J. Mol. Liq. 2017, 237, 466-472. [CrossRef]

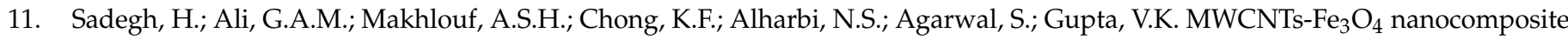
for $\mathrm{Hg}$ (II) high adsorption efficiency. J. Mol. Liq. 2018, 258, 345-353. [CrossRef]

12. Lee, S.P.; Ali, G.A.M.; Algarni, H.; Chong, K.F. Flake size-dependent adsorption of graphene oxide aerogel. J. Mol. Liq. 2019, 277, 175-180. [CrossRef]

13. Arabi, S.M.S.; Lalehloo, R.S.; Olyai, M.R.T.B.; Ali, G.A.M.; Sadegh, H. Removal of congo red azo dye from aqueous solution by $\mathrm{ZnO}$ nanoparticles loaded on multiwall carbon nanotubes. Phys. E Low-Dimens. Syst. Nanostruct. 2019, 106, 150-155. [CrossRef]

14. Karn, B.; Kuiken, T.; Otto, M. Nanotechnology and in Situ Remediation: A Review of the Benefits and Potential Risks. Environ. Health Perspect. 2009, 117, 1813-1831. [CrossRef]

15. Ganie, A.S.; Bano, S.; Khan, N.; Sultana, S.; Rehman, Z.; Rahman, M.M.; Sabir, S.; Coulon, F.; Khan, M.Z. Nanoremediation technologies for sustainable remediation of contaminated environments: Recent advances and challenges. Chemosphere 2021, 275, 130065. [CrossRef]

16. Akharame, M.O.; Fatoki, O.S.; Opeolu, B.O. Regeneration and Reuse of Polymeric Nanocomposites in Wastewater Remediation: The Future of Economic Water Management; Springer: Berlin/Heidelberg, Germany, 2019; Volume 76, pp. 647-681.

17. Chaturvedi, S.; Dave, P.N. Water purification using nanotechnology an emerging opportunities. Chem. Methodol. 2019, 3, 115-144.

18. Kumar, A.; Joshi, H.; Kumar, A. Remediation of Arsenic by Metal/Metal Oxide Based Nanocomposites/Nanohybrids: Contamination Scenario in Groundwater, Practical Challenges, and Future Perspectives. Sep. Purif. Rev. 2020, 50, 283-314. [CrossRef]

19. Blundell, S.P.; Owens, G. Evaluation of enhancement techniques for the dechlorination of DDT by nanoscale zero-valent iron. Chemosphere 2021, 264, 128324. [CrossRef] [PubMed]

20. Chen, J.; Dong, H.; Tian, R.; Li, R.; Xie, Q. Remediation of Trichloroethylene-Contaminated Groundwater by Sulfide-Modified Nanoscale Zero-Valent Iron Supported on Biochar: Investigation of Critical Factors. Water Air Soil Pollut. 2020, 231, 432. [CrossRef]

21. Gil-Díaz, M.; Álvarez, M.A.; Alonso, J.; Lobo, M.C. Effectiveness of nanoscale zero-valent iron for the immobilization of Cu and/or Ni in water and soil samples. Sci. Rep. 2020, 10, 15927. [CrossRef]

22. Mpouras, T.; Polydera, A.; Dermatas, D.; Verdone, N.; Vilardi, G. Multi wall carbon nanotubes application for treatment of $\mathrm{Cr}(\mathrm{VI})$-contaminated groundwater; Modeling of batch \& column experiments. Chemosphere 2021, $269,128749$.

23. Galdames, A.; Ruiz-Rubio, L.; Orueta, M.; Sánchez-Arzalluz, M.; Vilas-Vilela, J.L. Zero-Valent Iron Nanoparticles for Soil and Groundwater Remediation. Int. J. Environ. Res. Public Health 2020, 17, 5817. [CrossRef]

24. Araújo, R.; Castro, A.C.M.; Fiúza, A. The Use of Nanoparticles in Soil and Water Remediation Processes. Mater. Today Proc. 2015, 2, 315-320. [CrossRef]

25. Mukhopadhyay, R.; Sarkar, B.; Khan, E.; Alessi, D.S.; Biswas, J.K.; Manjaiah, K.M.; Eguchi, M.; Wu, K.C.W.; Yamauchi, Y.; Ok, Y.S. Nanomaterials for sustainable remediation of chemical contaminants in water and soil. Crit. Rev. Environ. Sci. Technol. 2021, 1-50. [CrossRef]

26. Savolainen, K.; Alenius, H.; Norppa, H.; Pylkkänen, L.; Tuomi, T.; Kasper, G. Risk assessment of engineered nanomaterials and nanotechnologies-A review. Toxicology 2010, 269, 92-104. [CrossRef]

27. Patil, S.S.; Shedbalkar, U.U.; Truskewycz, A.; Chopade, B.A.; Ball, A.S. Nanoparticles for environmental clean-up: A review of potential risks and emerging solutions. Environ. Technol. Innov. 2016, 5, 10-21. [CrossRef]

28. Pak, T.; de Lima Luz, L.F.; Tosco, T.; Costa, G.S.R.; Rosa, P.R.R.; Archilha, N.L. Pore-scale investigation of the use of reactive nanoparticles for in situ remediation of contaminated groundwater source. Proc. Natl. Acad. Sci. USA 2020, 117, 13366-13373. [CrossRef] [PubMed]

29. Galdames, A.; Mendoza, A.; Orueta, M.; de Soto García, I.S.; Sánchez, M.; Virto, I.; Vilas, J.L. Development of new remediation technologies for contaminated soils based on the application of zero-valent iron nanoparticles and bioremediation with compost. Resour. Effic. Technol. 2017, 3, 166-176. [CrossRef]

30. Thavamani, P.; Smith, E.; Kavitha, R.; Mathieson, G.; Megharaj, M.; Srivastava, P.; Naidu, R. Risk based land management requires focus beyond the target contaminants-A case study involving weathered hydrocarbon contaminated soils. Environ. Technol. Innov. 2015, 4, 98-109. [CrossRef]

31. Anyika, C.; Abdul Majid, Z.; Ibrahim, Z.; Zakaria, M.P.; Yahya, A. The impact of biochars on sorption and biodegradation of polycyclic aromatic hydrocarbons in soils-A review. Environ. Sci. Pollut. Res. 2015, 22, 3314-3341. [CrossRef]

32. Shayegan, H.; Ali, G.A.M.; Safarifard, V. Recent Progress in the Removal of Heavy Metal Ions from Water Using Metal-Organic Frameworks. ChemistrySelect 2020, 5, 124-146. [CrossRef]

33. Moreno-Sader, K.; García-Padilla, A.; Realpe, A.; Acevedo-Morantes, M.; Soares, J.B.P. Removal of Heavy Metal Water Pollutants $\left(\mathrm{Co}^{2+}\right.$ and $\left.\mathrm{Ni}^{2+}\right)$ Using Polyacrylamide/Sodium Montmorillonite (PAM/Na-MMT) Nanocomposites. ACS Omega 2019, 4, 10834-10844. [CrossRef] [PubMed]

34. Cameselle, C.; Chirakkara, R.A.; Reddy, K.R. Electrokinetic-enhanced phytoremediation of soils: Status and opportunities. Chemosphere 2013, 93, 626-636. [CrossRef]

35. Rodrigo, M.A.; Oturan, N.; Oturan, M.A. Electrochemically Assisted Remediation of Pesticides in Soils and Water: A Review. Chem. Rev. 2014, 114, 8720-8745. [CrossRef] [PubMed] 
36. Chang, K.-S.; Lo, W.-H.; Lin, W.-M.; Wen, J.-X.; Yang, S.-C.; Huang, C.-J.; Hsieh, H.-Y. Microwave-Assisted Thermal Remediation of Diesel Contaminated Soil. Eng. J. 2016, 20,93-100. [CrossRef]

37. Camenzuli, D.; Freidman, B.L.; Statham, T.M.; Mumford, K.A.; Gore, D.B. On-site and in situ remediation technologies applicable to metal-contaminated sites in Antarctica and the Arctic: A review. Polar Res. 2013, 32, 21522. [CrossRef]

38. Ossai, I.C.; Ahmed, A.; Hassan, A.; Hamid, F.S. Remediation of soil and water contaminated with petroleum hydrocarbon: A review. Environ. Technol. Innov. 2020, 17, 100526. [CrossRef]

39. Guerra, F.; Attia, M.; Whitehead, D.; Alexis, F. Nanotechnology for Environmental Remediation: Materials and Applications. Molecules 2018, 23, 1760. [CrossRef]

40. Huang, D.; Qin, X.; Peng, Z.; Liu, Y.; Gong, X.; Zeng, G.; Huang, C.; Cheng, M.; Xue, W.; Wang, X.; et al. Nanoscale zero-valent iron assisted phytoremediation of $\mathrm{Pb}$ in sediment: Impacts on metal accumulation and antioxidative system of Lolium perenne. Ecotoxicol. Environ. Saf. 2018, 153, 229-237. [CrossRef] [PubMed]

41. Peluffo, M.; Rosso, J.A.; Morelli, I.S.; Mora, V.C. Strategies for oxidation of PAHs in aged contaminated soil by batch reactors. Ecotoxicol. Environ. Saf. 2018, 151, 76-82. [CrossRef] [PubMed]

42. Fouad, O.A.; Makhlouf, S.A.; Ali, G.A.M.; El-Sayed, A.Y. Cobalt/silica nanocomposite via thermal calcination-reduction of gel precursors. Mater. Chem. Phys. 2011, 128, 70-76. [CrossRef]

43. Fouad, O.A.; Ali, G.A.M.; El-Erian, M.A.I.; Makhlouf, S.A. Humidity sensing properties of cobalt oxide/silica nanocomposites prepared via sol-gel and related routes. Nano 2012, 7, 1250038. [CrossRef]

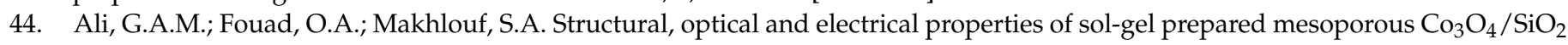
nanocomposites. J. Alloys Compd. 2013, 579, 606-611. [CrossRef]

45. Ali, G.A.M.; Fouad, O.A.; Makhlouf, S.A.; Yusoff, M.M.; Chong, K.F. $\mathrm{Co}_{3} \mathrm{O}_{4} / \mathrm{SiO}_{2}$ nanocomposites for supercapacitor application. J. Solid State Electrochem. 2014, 18, 2505-2512. [CrossRef]

46. Sadegh, H.; Ali, G.A.M.; Gupta, V.K.; Makhlouf, A.S.H.; Shahryari-ghoshekandi, R.; Nadagouda, M.N.; Sillanpää, M.; Megiel, E. The role of nanomaterials as effective adsorbents and their applications in wastewater treatment. J. Nanostruct. Chem. 2017, 7, 1-14. [CrossRef]

47. Abdel Ghafar, H.H.; Ali, G.A.M.; Fouad, O.A.; Makhlouf, S.A. Enhancement of adsorption efficiency of methylene blue on $\mathrm{Co}_{3} \mathrm{O}_{4} / \mathrm{SiO}_{2}$ nanocomposite. Desalin. Water Treat. 2015, 53, 2980-2989. [CrossRef]

48. Otto, M.; Floyd, M.; Bajpai, S. Nanotechnology for site remediation. Remediat. J. 2008, 19, 99-108. [CrossRef]

49. Shayegan, H.; Ali, G.A.M.; Safarifard, V. Amide-Functionalized Metal-Organic Framework for High Efficiency and Fast Removal of $\mathrm{Pb}$ (II) from Aqueous Solution. J. Inorg. Organomet. Polym. Mater. 2020, 30, 3170-3178. [CrossRef]

50. Ali, G.A.M.; Makhlouf, A.S.H. Fundamentals of Waste Recycling for Nanomaterial Manufacturing. In Waste Recycling Technologies for Nanomaterials Manufacturing; Makhlouf, A.S.H., Ali, G.A.M., Eds.; Springer International Publishing: Cham, Switzerland, 2021; pp. 3-24. [CrossRef]

51. Niemeyer, C.M. Nanoparticles, Proteins, and Nucleic Acids: Biotechnology Meets Materials Science. Angew. Chem. Int. Ed. 2001, 40, 4128-4158. [CrossRef]

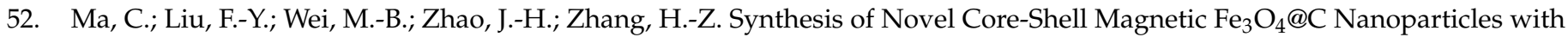
Carboxyl Function for Use as an Immobilisation Agent to Remediate Lead-Contaminated Soils. Pol. J. Environ. Stud. 2020, 29, 2273-2283. [CrossRef]

53. Meteku, B.E.; Huang, J.; Zeng, J.; Subhan, F.; Feng, F.; Zhang, Y.; Qiu, Z.; Aslam, S.; Li, G.; Yan, Z. Magnetic metal-organic framework composites for environmental monitoring and remediation. Coord. Chem. Rev. 2020, 413, 213261. [CrossRef]

54. Nematollahzadeh, A.; Seraj, S.; Mirzayi, B. Catecholamine coated maghemite nanoparticles for the environmental remediation: Hexavalent chromium ions removal. Chem. Eng. J. 2015, 277, 21-29. [CrossRef]

55. Zeng, H.; Zhai, L.; Qiao, T.; Yu, Y.; Zhang, J.; Li, D. Efficient removal of As(V) from aqueous media by magnetic nanoparticles prepared with Iron-containing water treatment residuals. Sci. Rep. 2020, 10, 9335. [CrossRef]

56. Zhu, S.; Wu, Y.; Qu, Z.; Zhang, L.; Yu, Y.; Xie, X.; Huo, M.; Yang, J.; Bian, D.; Zhang, H.; et al. Green synthesis of magnetic sodalite sphere by using groundwater treatment sludge for tetracycline adsorption. J. Clean. Prod. 2020, 247, 119140. [CrossRef]

57. Giahi, M.; Pathania, D.; Agarwal, S.; Ali, G.A.M.; Chong, K.F.; Gupta, V.K. Preparation of Mg-doped TiO 2 nanoparticles for photocatalytic degradation of some organic pollutants. Stud. Univ. Babes Bolyai Chem. 2019, 64, 7-18. [CrossRef]

58. Li, Q.; Chen, X.; Zhuang, J.; Chen, X. Decontaminating soil organic pollutants with manufactured nanoparticles. Environ. Sci. Pollut. Res. 2016, 23, 11533-11548. [CrossRef] [PubMed]

59. Yaqoob, A.A.; Parveen, T.; Umar, K.; Mohamad Ibrahim, M.N. Role of Nanomaterials in the Treatment of Wastewater: A Review. Water 2020, 12, 495. [CrossRef]

60. Baby, R.; Saifullah, B.; Hussein, M.Z. Carbon Nanomaterials for the Treatment of Heavy Metal-Contaminated Water and Environmental Remediation. Nanoscale Res. Lett. 2019, 14, 341. [CrossRef]

61. Benamar, A.; Mahjoubi, F.Z.; Ali, G.A.M.; Kzaiber, F.; Oussama, A. A chemometric method for contamination sources identification along the Oum Er Rbia river (Morocco). Bulg. Chem. Commun. 2020, 52, 159-171.

62. Zhang, W.-X. Nanoscale Iron Particles for Environmental Remediation: An Overview. J. Nanopart. Res. 2003, 5, 323-332. [CrossRef]

63. Mondal, A.; Dubey, B.K.; Arora, M.; Mumford, K. Porous media transport of iron nanoparticles for site remediation application: A review of lab scale column study, transport modelling and field-scale application. J. Hazard. Mater. 2021, 403, 123443. [CrossRef] 
64. Tian, H.; Liang, Y.; Yang, D.; Sun, Y. Characteristics of PVP-stabilised NZVI and application to dechlorination of soil-sorbed TCE with ionic surfactant. Chemosphere 2020, 239, 124807. [CrossRef]

65. Reginatto, C.; Cecchin, I.; Heineck, K.S.; Thomé, A.; Reddy, K.R. Use of Nanoscale Zero-Valent Iron for Remediation of Clayey Soil Contaminated with Hexavalent Chromium: Batch and Column Tests. Int. J. Environ. Res. Public Health 2020, 17, 1001. [CrossRef]

66. Shubair, T.; Eljamal, O.; Khalil, A.M.E.; Matsunaga, N. Multilayer system of nanoscale zero valent iron and Nano-Fe/Cu particles for nitrate removal in porous media. Sep. Purif. Technol. 2018, 193, 242-254. [CrossRef]

67. Xue, W.; Huang, D.; Zeng, G.; Wan, J.; Zhang, C.; Xu, R.; Cheng, M.; Deng, R. Nanoscale zero-valent iron coated with rhamnolipid as an effective stabilizer for immobilization of $\mathrm{Cd}$ and $\mathrm{Pb}$ in river sediments. J. Hazard. Mater. 2018, 341, 381-389. [CrossRef] [PubMed]

68. Apul, O.G.; Delgado, A.G.; Kidd, J.; Alam, F.; Dahlen, P.; Westerhoff, P. Carbonaceous nano-additives augment microwave-enabled thermal remediation of soils containing petroleum hydrocarbons. Environ. Sci. Nano 2016, 3, 997-1002. [CrossRef]

69. Zhang, Y.; Yang, J.; Zhong, L.; Liu, L. Effect of multi-wall carbon nanotubes on Cr(VI) reduction by citric acid: Implications for their use in soil remediation. Environ. Sci. Pollut. Res. 2018, 25, 23791-23798. [CrossRef]

70. Cheng, J.; Sun, Z.; Yu, Y.; Li, X.; Li, T. Effects of modified carbon black nanoparticles on plant-microbe remediation of petroleum and heavy metal co-contaminated soils. Int. J. Phytoremediat. 2019, 21, 634-642. [CrossRef] [PubMed]

71. Zhang, J.; Gong, J.-L.; Zeng, G.-M.; Yang, H.-C.; Zhang, P. Carbon nanotube amendment for treating dichlorodiphenyltrichloroethane and hexachlorocyclohexane remaining in Dong-ting Lake sediment-An implication for in-situ remediation. Sci. Total Environ. 2017, 579, 283-291. [CrossRef]

72. Abbasian, F.; Lockington, R.; Palanisami, T.; Megharaj, M.; Naidu, R. Multiwall carbon nanotubes increase the microbial community in crude oil contaminated fresh water sediments. Sci. Total Environ. 2016, 539, 370-380. [CrossRef]

73. Hua, S.; Gong, J.-L.; Zeng, G.-M.; Yao, F.-B.; Guo, M.; Ou, X.-M. Remediation of organochlorine pesticides contaminated lake sediment using activated carbon and carbon nanotubes. Chemosphere 2017, 177, 65-76. [CrossRef]

74. Naderi Peikam, E.; Jalali, M. Application of three nanoparticles $\left(\mathrm{Al}_{2} \mathrm{O}_{3}, \mathrm{SiO}_{2}\right.$ and $\left.\mathrm{TiO}_{2}\right)$ for metal-contaminated soil remediation (measuring and modeling). Int. J. Environ. Sci. Technol. 2018, 16, 7207-7220. [CrossRef]

75. Qiao, Y.; Wu, J.; Xu, Y.; Fang, Z.; Zheng, L.; Cheng, W.; Tsang, E.P.; Fang, J.; Zhao, D. Remediation of cadmium in soil by biochar-supported iron phosphate nanoparticles. Ecol. Eng. 2017, 106, 515-522. [CrossRef]

76. Baragaño, D.; Alonso, J.; Gallego, J.R.; Lobo, M.C.; Gil-Díaz, M. Zero valent iron and goethite nanoparticles as new promising remediation techniques for As-polluted soils. Chemosphere 2020, 238, 124624. [CrossRef]

77. Fan, L.; Song, J.; Bai, W.; Wang, S.; Zeng, M.; Li, X.; Zhou, Y.; Li, H.; Lu, H. Chelating capture and magnetic removal of non-magnetic heavy metal substances from soil. Sci. Rep. 2016, 6, 21027. [CrossRef]

78. Baragaño, D.; Alonso, J.; Gallego, J.R.; Lobo, M.C.; Gil-Díaz, M. Magnetite nanoparticles for the remediation of soils cocontaminated with As and PAHs. Chem. Eng. J. 2020, 399, 125809. [CrossRef]

79. Savage, N.; Diallo, M.S. Nanomaterials and Water Purification: Opportunities and Challenges. J. Nanopart. Res. 2005, 7, 331-342. [CrossRef]

80. Gong, Y.; Gai, L.; Tang, J.; Fu, J.; Wang, Q.; Zeng, E.Y. Reduction of Cr(VI) in simulated groundwater by FeS-coated iron magnetic nanoparticles. Sci. Total Environ. 2017, 595, 743-751. [CrossRef]

81. Gillham, R.W.; O’Hannesin, S.F. Enhanced Degradation of Halogenated Aliphatics by Zero-Valent Iron. Groundwater 1994, 32, 958-967. [CrossRef]

82. Wang, C.-B.; Zhang, W.-X. Synthesizing Nanoscale Iron Particles for Rapid and Complete Dechlorination of TCE and PCBs. Environ. Sci. Technol. 1997, 31, 2154-2156. [CrossRef]

83. Tosco, T.; Petrangeli Papini, M.; Cruz Viggi, C.; Sethi, R. Nanoscale zerovalent iron particles for groundwater remediation: A review. J. Clean. Prod. 2014, 77, 10-21. [CrossRef]

84. Lin, K.-S.; Mdlovu, N.V.; Chen, C.-Y.; Chiang, C.-L.; Dehvari, K. Degradation of TCE, PCE, and 1,2-DCE DNAPLs in contaminated groundwater using polyethylenimine-modified zero-valent iron nanoparticles. J. Clean. Prod. 2018, 175, 456-466. [CrossRef]

85. Dong, H.; Zhang, C.; Deng, J.; Jiang, Z.; Zhang, L.; Cheng, Y.; Hou, K.; Tang, L.; Zeng, G. Factors influencing degradation of trichloroethylene by sulfide-modified nanoscale zero-valent iron in aqueous solution. Water Res. 2018, 135, 1-10. [CrossRef]

86. Zhu, F.; Ma, S.; Liu, T.; Deng, X. Green synthesis of nano zero-valent iron/Cu by green tea to remove hexavalent chromium from groundwater. J. Clean. Prod. 2018, 174, 184-190. [CrossRef]

87. Lico, D.; Vuono, D.; Siciliano, C.; Nagy, J.B.; De Luca, P. Removal of unleaded gasoline from water by multi-walled carbon nanotubes. J. Environ. Manag. 2019, 237, 636-643. [CrossRef] [PubMed]

88. Liang, J.; Liu, J.; Yuan, X.; Dong, H.; Zeng, G.; Wu, H.; Wang, H.; Liu, J.; Hua, S.; Zhang, S.; et al. Facile synthesis of aluminadecorated multi-walled carbon nanotubes for simultaneous adsorption of cadmium ion and trichloroethylene. Chem. Eng. J. 2015, 273, 101-110. [CrossRef]

89. Mdlovu, N.V.; Lin, K.-S.; Chen, C.-Y.; Mavuso, F.A.; Kunene, S.C.; Carrera Espinoza, M.J. In-situ reductive degradation of chlorinated DNAPLs in contaminated groundwater using polyethyleneimine-modified zero-valent iron nanoparticles. Chemosphere 2019, 224, 816-826. [CrossRef]

90. Ou, J.-H.; Sheu, Y.-T.; Tsang, D.C.W.; Sun, Y.-J.; Kao, C.-M. Application of iron/aluminum bimetallic nanoparticle system for chromium-contaminated groundwater remediation. Chemosphere 2020, 256, 127158. [CrossRef] [PubMed] 
91. Wang, T.; Liu, Y.; Wang, J.; Wang, X.; Liu, B.; Wang, Y. In-situ remediation of hexavalent chromium contaminated groundwater and saturated soil using stabilized iron sulfide nanoparticles. J. Environ. Manag. 2019, 231, 679-686. [CrossRef] [PubMed]

92. Xie, W.; Liang, Q.; Qian, T.; Zhao, D. Immobilization of selenite in soil and groundwater using stabilized Fe-Mn binary oxide nanoparticles. Water Res. 2015, 70, 485-494. [CrossRef] [PubMed]

93. Dong, H.; Jiang, Z.; Deng, J.; Zhang, C.; Cheng, Y.; Hou, K.; Zhang, L.; Tang, L.; Zeng, G. Physicochemical transformation of $\mathrm{Fe} / \mathrm{Ni}$ bimetallic nanoparticles during aging in simulated groundwater and the consequent effect on contaminant removal. Water Res. 2018, 129, 51-57. [CrossRef]

94. Huang, Y.; Keller, A.A. EDTA functionalized magnetic nanoparticle sorbents for cadmium and lead contaminated water treatment. Water Res. 2015, 80, 159-168. [CrossRef]

95. Li, D.; Egodawatte, S.; Kaplan, D.I.; Larsen, S.C.; Serkiz, S.M.; Seaman, J.C. Functionalized magnetic mesoporous silica nanoparticles for U removal from low and high pH groundwater. J. Hazard. Mater. 2016, 317, 494-502. [CrossRef] [PubMed]

96. Alani, O.A.; Ari, H.A.; Offiong, N.-A.O.; Alani, S.O.; Li, B.; Zeng, Q.-r.; Feng, W. Catalytic Removal of Selected Textile Dyes Using Zero-Valent Copper Nanoparticles Loaded on Filter Paper-Chitosan-Titanium Oxide Heterogeneous Support. J. Polym. Environ. 2021, 29, 2825-2839. [CrossRef]

97. Ari, H.A.; Alani, O.A.; Zeng, Q.-r.; Ugya, Y.A.; Offiong, N.-A.O.; Feng, W. Enhanced UV-assisted Fenton performance of nanostructured biomimetic $\alpha-\mathrm{Fe}_{2} \mathrm{O}_{3}$ on degradation of tetracycline. J. Nanostruct. Chem. 2021. [CrossRef]

98. Dissanayake, N.M.; Current, K.M.; Obare, S.O. Mutagenic Effects of Iron Oxide Nanoparticles on Biological Cells. Int. J. Mol. Sci. 2015, 16, 23482-23516. [CrossRef] [PubMed]

99. Current, K.M.; Dissanayake, N.M.; Obare, S.O. Effect of Iron Oxide Nanoparticles and Amoxicillin on Bacterial Growth in the Presence of Dissolved Organic Carbon. Biomedicines 2017, 5, 55. [CrossRef] [PubMed]

100. Du, W.; Xu, Y.; Yin, Y.; Ji, R.; Guo, H. Risk assessment of engineered nanoparticles and other contaminants in terrestrial plants. Curr. Opin. Environ. Sci. Health 2018, 6, 21-28. [CrossRef]

101. Shrivastava, M.; Srivastav, A.; Gandhi, S.; Rao, S.; Roychoudhury, A.; Kumar, A.; Singhal, R.K.; Jha, S.K.; Singh, S.D. Monitoring of engineered nanoparticles in soil-plant system: A review. Environ. Nanotechnol. Monit. Manag. 2019, 11, 100218. [CrossRef]

102. Hristozov, D.R.; Gottardo, S.; Critto, A.; Marcomini, A. Risk assessment of engineered nanomaterials: A review of available data and approaches from a regulatory perspective. Nanotoxicology 2012, 6, 880-898. [CrossRef]

103. Gómez-Sagasti, M.T.; Epelde, L.; Anza, M.; Urra, J.; Alkorta, I.; Garbisu, C. The impact of nanoscale zero-valent iron particles on soil microbial communities is soil dependent. J. Hazard. Mater. 2019, 364, 591-599. [CrossRef]

104. Dong, H.; Xie, Y.; Zeng, G.; Tang, L.; Liang, J.; He, Q.; Zhao, F.; Zeng, Y.; Wu, Y. The dual effects of carboxymethyl cellulose on the colloidal stability and toxicity of nanoscale zero-valent iron. Chemosphere 2016, 144, 1682-1689. [CrossRef]

105. Chaithawiwat, K.; Vangnai, A.; McEvoy, J.M.; Pruess, B.; Krajangpan, S.; Khan, E. Impact of nanoscale zero valent iron on bacteria is growth phase dependent. Chemosphere 2016, 144, 352-359. [CrossRef] [PubMed]

106. Cheng, Y.; Dong, H.; Lu, Y.; Hou, K.; Wang, Y.; Ning, Q.; Li, L.; Wang, B.; Zhang, L.; Zeng, G. Toxicity of sulfide-modified nanoscale zero-valent iron to Escherichia coli in aqueous solutions. Chemosphere 2019, 220, 523-530. [CrossRef]

107. Li, Z.; Wang, L.; Wu, J.; Xu, Y.; Wang, F.; Tang, X.; Xu, J.; Ok, Y.S.; Meng, J.; Liu, X. Zeolite-supported nanoscale zero-valent iron for immobilization of cadmium, lead, and arsenic in farmland soils: Encapsulation mechanisms and indigenous microbial responses. Environ. Pollut. 2020, 260, 114098. [CrossRef] [PubMed]

108. Lam, C.W. Pulmonary Toxicity of Single-Wall Carbon Nanotubes in Mice 7 and 90 Days After Intratracheal Instillation. Toxicol. Sci. 2003, 77, 126-134. [CrossRef] [PubMed]

109. Song, B.; Chen, M.; Ye, S.; Xu, P.; Zeng, G.; Gong, J.; Li, J.; Zhang, P.; Cao, W. Effects of multi-walled carbon nanotubes on metabolic function of the microbial community in riverine sediment contaminated with phenanthrene. Carbon 2019, $144,1-7$. [CrossRef]

110. Vilardi, G.; Mpouras, T.; Dermatas, D.; Verdone, N.; Polydera, A.; Di Palma, L. Nanomaterials application for heavy metals recovery from polluted water: The combination of nano zero-valent iron and carbon nanotubes. Competitive adsorption non-linear modeling. Chemosphere 2018, 201, 716-729. [CrossRef]

111. Zhang, R.; Zhang, N.; Fang, Z. In situ remediation of hexavalent chromium contaminated soil by CMC-stabilized nanoscale zero-valent iron composited with biochar. Water Sci. Technol. 2018, 77, 1622-1631. [CrossRef]

112. Qian, L.; Chen, Y.; Ouyang, D.; Zhang, W.; Han, L.; Yan, J.; Kvapil, P.; Chen, M. Field demonstration of enhanced removal of chlorinated solvents in groundwater using biochar-supported nanoscale zero-valent iron. Sci. Total Environ. 2020, 698, 134215. [CrossRef]

113. Alabresm, A.; Chen, Y.P.; Decho, A.W.; Lead, J. A novel method for the synergistic remediation of oil-water mixtures using nanoparticles and oil-degrading bacteria. Sci. Total Environ. 2018, 630, 1292-1297. [CrossRef] [PubMed]

114. Czinnerová, M.; Vološčuková, O.; Marková, K.; Ševců, A.; Černík, M.; Nosek, J. Combining nanoscale zero-valent iron with electrokinetic treatment for remediation of chlorinated ethenes and promoting biodegradation: A long-term field study. Water Res. 2020, 175, 115692. [CrossRef] [PubMed]

115. Boente, C.; Sierra, C.; Martínez-Blanco, D.; Menéndez-Aguado, J.M.; Gallego, J.R. Nanoscale zero-valent iron-assisted soil washing for the removal of potentially toxic elements. J. Hazard. Mater. 2018, 350, 55-65. [CrossRef] [PubMed] 
116. Qu, G.; Kou, L.; Wang, T.; Liang, D.; Hu, S. Evaluation of activated carbon fiber supported nanoscale zero-valent iron for chromium (VI) removal from groundwater in a permeable reactive column. J. Environ. Manag. 2017, 201, 378-387. [CrossRef]

117. Huang, J.; Yi, S.; Zheng, C.; Lo, I.M.C. Persulfate activation by natural zeolite supported nanoscale zero-valent iron for trichloroethylene degradation in groundwater. Sci. Total Environ. 2019, 684, 351-359. [CrossRef] [PubMed] 